\title{
Partitioning of chromium between garnet and clinopyroxene: first-principle modelling versus metamorphic assemblages
}

\author{
Sarah Figowy, Benoît Dubacq, Yves Noël, and Philippe d'Arco \\ Sorbonne Université, CNRS-INSU, Institut des Sciences de la Terre de Paris, \\ ISTeP UMR 7193, 75005 Paris, France
}

Correspondence: Sarah Figowy (sarah.figowy@ sorbonne-universite.fr)

Received: 30 December 2019 - Revised: 28 May 2020 - Accepted: 15 June 2020 - Published: 3 July 2020

\begin{abstract}
Understanding the geochemical behaviour of trace and minor elements in mineral assemblages is of primary importance to study small- and large-scale geological processes. Partition coefficients are frequently used to model the chemical evolution of minerals and fluids during melting and in metamorphic rocks of all grades. However, kinetic effects hampering equilibrium partitioning may invalidate the modelling. This study aims at calculating partition coefficients and testing their applicability in natural mineral assemblages, choosing $\mathrm{Cr}$ in garnet and clinopyroxene via exchange with $\mathrm{Al}$ as a case study. First-principle modelling has been combined with measurements and element mapping to estimate partition coefficients for $\mathrm{Cr}$ and the deviation from equilibrium. Results highlight the role of crystal chemistry over the strain field around point defects, controlling the dynamics of the $\mathrm{Cr}^{3+}=\mathrm{Al}^{3+}$ exchange between clinopyroxene and garnet. Ab initio calculations allowed estimation of $\mathrm{Cr}$ partition coefficients between garnet and clinopyroxene, using a thermodynamic approach based on endmembers and mixing models simplified for trace element behaviour. $\mathrm{The}^{3+}=\mathrm{Al}^{3+}$ exchange reaction between garnet and the jadeite component of clinopyroxene depends on the grossular and pyrope content, with $\mathrm{Cr}$ preferentially incorporated into grossular over jadeite but preferentially incorporated into jadeite over pyrope. Comparison of predicted partition coefficients to measured concentrations in natural samples, together with element mapping, shows large disequilibrium. Cr-rich and $\mathrm{Cr}$-poor sectors exhibit disequilibrium attributed to slow diffusivity of $\mathrm{Cr}$ during crystal growth and interface-coupled dissolution-precipitation, even for garnetclinopyroxene assemblages crystallized around $850^{\circ} \mathrm{C}$.
\end{abstract}

\section{Introduction}

Trace and minor elements have been used as tracers of many geological processes and understanding their geochemical behaviour is highly important to petrology. The distribution of trace elements - rare earth elements (REEs) in particular - gives information on the source material of lavas (e.g. Helmke, 1972, using REEs, Co, Hf and $\mathrm{Cr}$ on lunar basalts; Hofmann, 1988), on the evolution of magmas (e.g. Allègre et al., 1977; Shorttle et al., 2016), and on fluid-rock interactions during diagenesis and metamorphic conditions of all grades (Wigley et al., 2013; Boutoux et al., 2014). Numerous studies of the isotopic signature of trace elements also rely on partition coefficients with huge implications on our under- standing of large- and small-scale processes through element fractionation (e.g. Chauvel et al., 2008; Pabst et al., 2012).

Trace and minor elements can also provide information on how equilibrium is reached or hampered in metamorphic rocks. For example, sectors locally enriched in trace elements and cross-cutting major element zoning have been described and interpreted as disequilibrium features in mineral assemblages up to granulite facies (e.g. Chernoff and Carlson, 1999; Martin, 2009; Kohn, 2014; Carlson et al., 2015). Trace and minor elements are also used to investigate diffusivity in minerals and associated timescales (John et al., 2012; Ague and Axler, 2016), constrain pressure-temperature-time paths, and study metasomatism (e.g. Hickmott and Shimizu, 1990; Rubatto and Hermann, 2003; Angiboust et al., 2014; 
Kohn, 2014). However, going beyond a qualitative description of kinetic features and quantifying the amount of disequilibrium shown by trace elements in a sample remains challenging.

The partitioning of trace and minor elements between minerals and/or fluids remains poorly constrained in many cases, on both theoretical and applied grounds (Albarède and Bottinga, 1972; Dubacq and Plunder, 2018). Studies of strain fields around defects and decoration provide a robust starting frame (e.g. Carpenter et al., 2009), and several approaches and thermodynamic formalisms are available (Wagner et al., 2017; Dubacq and Plunder, 2018). Unfortunately, the dependency of partition coefficients on composition is not trivial, and the vast number of solid solutions, even in common mineral assemblages, is daunting. The dependency on composition complicates applications as incorporation of small amounts of additional components to solid solutions may affect partitioning dramatically (e.g. Dubacq and Plunder, 2018 , show that a $5 \%$ addition of majorite in pyrope garnet increases the garnet-melt partition coefficient by orders of magnitude). Modelling approaches for the incorporation of trace elements in mineral structures are also challenged by the necessary large number of atoms in simulations, as for melts (e.g. Wagner et al., 2017). Despite this complexity, theoretical modelling provides in-depth understanding of defect incorporation in mineral structures, linking strain to energy differences independently of experimental petrology and measurements.

Chromium $(\mathrm{Cr})$, regularly found in trivalent form in various concentrations in pelitic and mafic metamorphic rocks, has been chosen here as a proxy to bigger and more complex trivalent cations such as REEs. $\mathrm{In} \mathrm{Cr}^{3+}$ form, the $\mathrm{d}$ shell of $\mathrm{Cr}$ is partially filled. The resulting electronic configuration, with smaller shells, is easier to model than that of REEs. The incorporation of $\mathrm{Cr}^{3+}$ in silicates is generally explained by the homovalent substitution ${ }^{\mathrm{Y}} \mathrm{Cr}^{3+}={ }^{\mathrm{Y}} \mathrm{Al}^{3+}$, where octahedral sites are highly favoured for hosting $\mathrm{Cr}^{3+}$ as justified by the crystal field theory and shown by X-ray diffraction (XRD) studies (e.g. Burns, 1976; Ohashi, 1980; Langer and Andrut, 1996; Yang et al., 1999; Urusov and Taran, 2012).

The present study models the $\mathrm{Cr}^{3+}=\mathrm{Al}^{3+}$ substitution with first-principle calculations in garnet and clinopyroxene with varying $\mathrm{Cr}^{3+}$ concentration, shedding light on the impact of crystal chemistry over strain, energy differences and partitioning. The environment of the exchange site plays a key role in strain accommodation during relaxation. Results are compared with measurements of the distribution of $\mathrm{Cr}$ in selected metamorphic rock samples of medium and high grade, highlighting disequilibrium features. Interfacecoupled dissolution-precipitation appears to control the distribution of $\mathrm{Cr}$ due to its very low effective mobility.

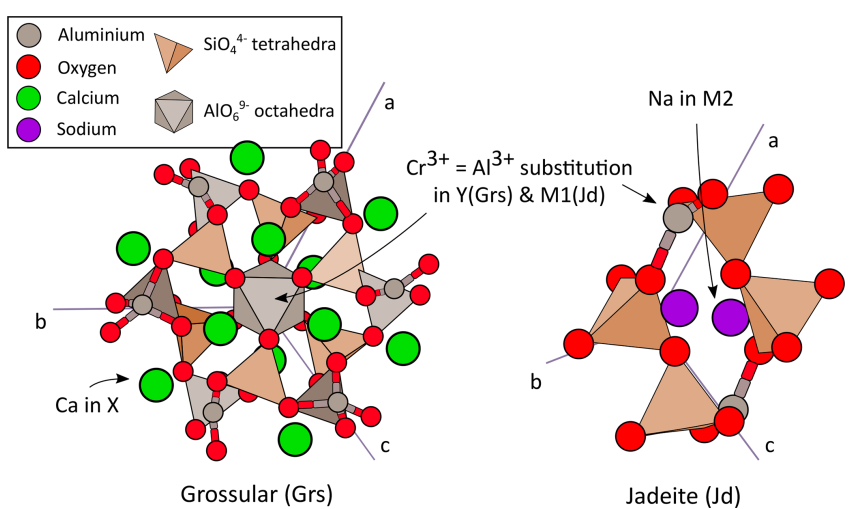

Figure 1. Crystal structures of grossular and jadeite. Trivalent $\mathrm{Cr}^{3+}$ substitutes with $\mathrm{Al}^{3+}$ in $\mathrm{AlO}_{6}^{9-}$ octahedra in both minerals (Y site). The dodecahedral site $(\mathrm{X})$ of grossular incorporates $\mathrm{Ca}^{2+}$ and that of jadeite $\mathrm{Na}^{+}$.

\section{Nomenclature, material and methods}

\subsection{Crystal chemistry and terminology}

The garnet-clinopyroxene is a common assemblage appearing in varied conditions. It is typical of eclogite facies rocks when the clinopyroxene includes a significant jadeite component.

Silicate garnets belong to the $I a \overline{3 d}$ space group (e.g. Smyth and Bish, 1988). They are characterized by a variety of solid solutions, with the general formula $\mathrm{X}_{3} \mathrm{Y}_{2} \mathrm{Si}_{3} \mathrm{O}_{12}$, where $\mathrm{X}$ is the dodecahedral site (hosting divalent cations, mainly $\mathrm{Fe}^{2+}, \mathrm{Mn}^{2+}, \mathrm{Mg}^{2+}, \mathrm{Ca}^{2+}$ ) and $\mathrm{Y}$ the octahedral site (hosting trivalent cations, mainly $\mathrm{Al}^{3+}, \mathrm{Cr}^{3+}, \mathrm{Fe}^{3+}$; Geiger, 1999; Lacivita et al., 2015). $\mathrm{SiO}_{4}^{4-}$ tetrahedra are not bonded to each other and share corners with $\mathrm{YO}_{6}$ octahedra, as shown in Fig. 1 for grossular $\left(\mathrm{Ca}_{3} \mathrm{Al}_{2} \mathrm{Si}_{3} \mathrm{O}_{12}\right)$. Incorporation of $\mathrm{Cr}$ takes place in octahedra and is modelled as a $\mathrm{Cr}^{3+}=$ $\mathrm{Al}^{3+}$ exchange: uvarovite $\left(\mathrm{Ca}_{3} \mathrm{Cr}_{2} \mathrm{Si}_{3} \mathrm{O}_{12}\right)$ is the calcic endmember of this binary solid solution $\mathrm{Ca}_{3}\left(\mathrm{Al}_{1-x} \mathrm{Cr}_{x}\right)_{2} \mathrm{Si}_{3} \mathrm{O}_{12}$ with grossular (Langer et al., 2004; Tsujimori and Liou, 2004). In magnesian garnet, pyrope $\left(\mathrm{Mg}_{3} \mathrm{Al}_{2} \mathrm{Si}_{3} \mathrm{O}_{12}\right)$ forms a similar solid solution with knorringite $\left(\mathrm{Mg}_{3} \mathrm{Cr}_{2} \mathrm{Si}_{3} \mathrm{O}_{12}\right)$.

Clinopyroxene is a subgroup of pyroxene minerals. It is a monoclinic inosilicate with the $C 2 / c$ space group (Smyth and $\mathrm{Bish}, 1988) . \mathrm{SiO}_{4}^{4-}$ tetrahedra form simple chains connected by corners (Fig. 1). Clinopyroxene has the general formula $M 2 M 1 \mathrm{Si}_{2} \mathrm{O}_{6}$ where $M 1$ and $M 2$ are octahedral sites (with $M 2$ frequently including $\mathrm{Ca}^{2+}, \mathrm{Na}^{+}$and $M 1 \mathrm{Al}^{3+}$, $\left.\mathrm{Cr}^{3+}, \mathrm{Fe}^{3+}, \mathrm{Mg}^{2+}\right)$. As in garnet, $\mathrm{Cr}$ is mostly incorporated in octahedral sites and modelled with the same $\mathrm{Cr}^{3+}$ $=\mathrm{Al}^{3+}$ exchange, defining a solid solution between kosmochlor $\left(\mathrm{NaCrSi}_{2} \mathrm{O}_{6}\right)$ and an aluminous endmember such as jadeite ( $\mathrm{NaAlSi}_{2} \mathrm{O}_{6}$; Tsujimori and Liou, 2004; Reznitsky et al., 2011; Secco et al., 2002). 
Mineral abbreviations in this article originate from Whitney and Evans (2010), except for knorringite (Kno). For results of modelling in solid solutions, abbreviations are built with a radical indicating the original defect-free mineral and a prefix with the incorporated element, such as $\mathrm{CrGrs}$ for $\mathrm{Cr}$ doped grossular and AlUv for Al-doped uvarovite.

\subsection{Ab initio modelling}

\subsubsection{Protocol}

$\mathrm{Ab}$ initio modelling provides very precise estimations of energy, volume and strain in defect-bearing minerals, with potential for systematic studies of partitioning between minerals. Calculations have been performed on periodic crystals with the CRYSTAL17 program (Dovesi et al., 2005, 2018). CRYSTAL17 uses orbitals as a linear combination of Gaussian functions and computes ground state energy directly from the Hamiltonian, using quantum equations and approximations that allow solving Schrödinger's equation for multielectronic atoms (see Sherman, 2016). Complete technical description is given in Dovesi et al. (2018). The B3LYP density functional has been selected as it is simply implemented with a localized Gaussian basis set and has shown excellent agreement with experimental data, including vibrational spectroscopy (Pascale, 2004; De La Pierre and Belmonte, 2016; Sherman, 2016).

The $\mathrm{Al}^{3+}=\mathrm{Cr}^{3+}$ substitution is simulated by directly replacing an $\mathrm{Al}^{3+}$ ion (ionic radius: $0.535 \AA$ after Shannon, 1976) by a $\mathrm{Cr}^{3+}$ defect (ionic radius: $0.615 \AA$ after Shannon, 1976) in aluminous endmembers or $\mathrm{a} \mathrm{Cr}^{3+}$ ion by $\mathrm{Al}^{3+}$ in Cr-rich minerals. Structure relaxation triggers deformation around the defect, by altering interatomic distances and/or changing angles to stabilize the structure and decrease lattice energy (Urusov and Taran, 2012). For each structure, CRYSTAL17 first computes the ground state energy by energy minimization using an iterative self-consistent field method (Dovesi et al., 2018) until the energy difference between two cycles becomes less than $10^{-7} \mathrm{Ha}$. Chromium has been locked in ferromagnetic state during the first eight cycles in order to stabilize its spin and maintain electro-neutrality during the cycles. The whole crystal geometry is then optimized following a second iterative procedure, until convergence criteria are satisfied (arbitrary units of the software): maximum energy gradient $(0.00045)$, RMS gradient (0.0003), maximum atom displacement (0.0018) and associated RMS (0.0012). Modelled optimized energies allow computation of a defect energy, which corresponds to the difference between the energetic state of the mineral with and without defect (e.g. Allan et al., 2003). The defect energy is expressed per mole of defect and sums the excess enthalpy of the mineral and the intrinsic energetic difference between $\mathrm{Cr}^{3+}$ and $\mathrm{Al}^{3+}$. The latter does not vary with mineral structure. Consequently, differences in the defect energies of garnet and clinopyroxene reflect differences in excess enthalpy, allowing us to access Gibbs energies of reactions and partition coefficients as detailed below.

Grossular-uvarovite, pyrope-knorringite and jadeitekosmochlor solid solutions involve homovalent $\mathrm{Al}^{3+}=\mathrm{Cr}^{3+}$ substitution in one site. Computations have first been made on primitive cells for endmembers. Then solid solutions are modelled by incorporating one defect in increasingly large cells, always starting from the endmember structure. Supercells have been used and are expressed using $S_{n}$, with $n$ the volume factor between the primitive cell and the supercell. Larger supercells have more dilute defects, closer to trace element behaviour but with space group symmetry constraints released, allowing strain localization around the defect. The thermodynamics of non-ideal mixtures states that partition coefficients vary non-linearly with concentration, reaching a fixed value at the dilution limit - when elements behave as trace. This corresponds to the concentration where defects are sufficiently far from each other to not interact, so that defect energies stay constant with decreasing defect concentration. In this procedure, defect atoms are distributed homogeneously in the structure, as far apart from one another as possible, to reproduce the effect of a trace point defect. Ordering is not considered further, implying that computed structures for solid solutions far from endmembers (e.g. $50 \%$ grossular $50 \%$ uvarovite) are of little interest as their configuration is likely not that of equilibrium, which will be temperature dependent (see e.g. Dove et al., 1996). It is noted that defect energies have the dimension of enthalpy and do not vary with pressure and temperature. Therefore, vibrational contributions to the Gibbs energy of exchange reactions and partition coefficients are neglected as they largely cancel out in the exchange reaction, unlike differences in lattice enthalpies which are of larger magnitude.

\subsubsection{Thermodynamic formalism}

In this section, partitioning of $\mathrm{Cr}$ between garnet and clinopyroxene is presented with the grossular and jadeite endmembers. Similar equations are written for pyrope-knorringite and jadeite-kosmochlor binary solid solutions. The partition coefficient $D_{\mathrm{Cr}}^{\mathrm{Grs} / \mathrm{Jd}}$ quantifies the distribution of $\mathrm{Cr}^{3+}$ between grossular garnet and jadeite clinopyroxene at equilibrium. $D_{\mathrm{Cr}}^{\mathrm{Gr} / \mathrm{Jd}}$ is defined as

$D_{\mathrm{Cr}}^{\mathrm{Grs} / \mathrm{Jd}}=\frac{x_{\mathrm{Cr}}^{\mathrm{Gr}}}{x_{\mathrm{Cr}}^{\mathrm{Jd}}}$,

where $x_{\mathrm{Cr}}^{\mathrm{Grs}}$ is the concentration of $\mathrm{Cr}$ in grossular and $x_{\mathrm{Cr}}^{\mathrm{Jd}}$ that of $\mathrm{Cr}$ in jadeite (e.g. Morse, 2015). Here concentrations are expressed from the number of moles of elements per formula unit using the usual $\mathrm{O}_{12}$ anion basis for garnet and $\mathrm{O}_{6}$ for clinopyroxene. Incorporation of $\mathrm{Cr}^{3+}$ into the mineral structure is modelled as an exchange reaction with a liquid $L$ (e.g. a melt or supercritical aqueous fluid) as in Blundy and Wood (1994): 
$\mathrm{Grs}+\mathrm{Cr}^{3+}(L)=\mathrm{CrGrs}+\mathrm{Al}^{3+}(L)$,

$\mathrm{Jd}+\mathrm{Cr}^{3+}(L)=\mathrm{CrJd}+\mathrm{Al}^{3+}(L)$.

The grossular-jadeite exchange is the difference between Reactions (R1) and (R2), yielding (see Dubacq and Plunder, 2018)

$\mathrm{Grs}+\mathrm{CrJd}=\mathrm{CrGrs}+\mathrm{Jd}$.

The standard Gibbs free energy of reaction $\Delta G_{\mathrm{r}}{ }^{\circ}$ is the difference between the energetic state of products and reactants in the exchange Reaction (R3). As defect energies $U_{\mathrm{d}}$ are the differences between mineral endmembers and their substituted counterparts (e.g. $U_{\mathrm{d}}^{\mathrm{Cr} / \mathrm{Grs}}=E_{\mathrm{CrGrs}}-E_{\mathrm{Grs}}$ ), $\Delta G_{\mathrm{r}}{ }^{\circ}$ is simply the difference in defect energies, such as for $\Delta G_{\mathrm{r}}{ }^{\circ}{ }_{3}$ :

$\Delta G_{\mathrm{r}}^{\circ} 3=U_{\mathrm{d}}^{\mathrm{Cr} / \mathrm{Grs}}-U_{\mathrm{d}}^{\mathrm{Cr} / \mathrm{Jd}}$.

The constant of reaction $K$ is linked to temperature $T$, the gas constant $R$ and $\Delta G_{\mathrm{r}}{ }^{\circ} i$. Therefore, $K$ may be expressed as a function of defect energies:

$$
\begin{aligned}
K=\frac{a_{\mathrm{Cr}}^{\mathrm{Grs}} \cdot a_{\mathrm{Al}}^{\mathrm{Jd}}}{a_{\mathrm{Cr}}^{\mathrm{Jd}} \cdot a_{\mathrm{Al}}^{\mathrm{Grs}}}= & \exp \left(\frac{-\Delta G_{\mathrm{r}}^{\circ} 3}{R T}\right) \\
& =\exp \left(\frac{-U_{d}^{\mathrm{Cr} / \mathrm{Grs}}+U_{\mathrm{d}}^{\mathrm{Cr} / \mathrm{Jd}}}{R T}\right) .
\end{aligned}
$$

Assuming ideal mixing at trace concentrations, activities are assimilated to concentrations, yielding

$$
K=\frac{x_{\mathrm{Cr}}^{\mathrm{Grs}} \cdot x_{\mathrm{Al}}^{\mathrm{Jd}}}{x_{\mathrm{Cr}}^{\mathrm{Jd}} \cdot x_{\mathrm{Al}}^{\mathrm{Grs}}}=\frac{D_{\mathrm{Cr}}^{\mathrm{Grs} / \mathrm{Jd}}}{D_{\mathrm{Al}}^{\mathrm{Grs} / \mathrm{Jd}}} .
$$

The partition coefficient $D_{\mathrm{Cr}}^{\mathrm{Grs} / \mathrm{Jd}}$ is obtained with

$D_{\mathrm{Cr}}^{\mathrm{Grs} / \mathrm{Jd}}=\frac{x_{\mathrm{Al}}^{\mathrm{Grs}}}{x_{\mathrm{Al}}^{\mathrm{Jd}}} \exp \left(\frac{-U_{\mathrm{d}}^{\mathrm{Cr} / \mathrm{Grs}}+U_{\mathrm{d}}^{\mathrm{Cr} / \mathrm{Jd}}}{R T}\right)$,

where defect energies are estimated with CRYSTAL17. The final set of reactions includes $\mathrm{Cr}$ exchange between grossular and jadeite (Reaction R3) and between pyrope and jadeite (Reaction R4) as well as the $\mathrm{Al}$ exchange reactions between uvarovite and kosmochlor (Reaction R5) and between knorringite and kosmochlor (Reaction R6):

$\operatorname{Prp}+\mathrm{CrJd}=\mathrm{CrPrp}+\mathrm{Jd}$,

$\mathrm{Uv}+\mathrm{AlKos}=\mathrm{AlUv}+\mathrm{Kos}$,

$\mathrm{Kno}+\mathrm{AlKos}=\mathrm{AlKno}+\mathrm{Kos}$.

Equation (5) is also used for natural samples to estimate theoretical partition coefficients between garnet and pyroxene at the measured composition. In that case the value used for the defect energy is that of the endmembers weighted by their fraction, which is equivalent to applying an ideal mixing model for trace-element-doped endmembers. For simplicity, the $\mathrm{Fe}^{2+}$ component of garnet (almandine) has been attributed to $\mathrm{Mg}$ (pyrope), its closest equivalent in terms of cation size, possibly altering the calculated partition coefficient in favour of pyroxene.

\subsection{Description of samples}

Four samples have been selected from research collections. Sample mineralogy and crystallization conditions are summarized in Table 1. Samples MA1435 and MA1438 originate from the metamorphic sole of the Mount Albert Ordovician ophiolitic massif (Quebec, Canada). Both are garnetclinopyroxene-bearing mafic amphibolites named amphibolite du diable metamorphosed at granulite facies conditions along a clockwise pressure-temperature path (described by Dubacq et al., 2019). They are mainly composed of garnet porphyroblasts $(30 \%-40 \%)$, clinopyroxene $(30 \%-40 \%)$, green amphibole and plagioclase with minor epidote, quartz, rutile and Fe-oxides (Fig. 2e). Orthopyroxene is not present. Garnet rims show symplectitic textures with clinopyroxene, amphibole and/or plagioclase. Clinopyroxene size is comprised between hundreds of micrometres to $2 \mathrm{~mm}$.

The L3515 sample (Fig. 2a) is a Fe-Ti-rich metagabbro from the eclogitic slice of Monte Viso, a meta-ophiolitic complex of the Western Alps, and has been described by Locatelli (2017). It has experienced successive fluid circulation events together with brecciation, recorded by veins and mineral assemblages with varying trace element content. This has been interpreted as progressive opening of the system with increasing contribution of serpentinite-derived fluids (Locatelli, 2017). About half of the thin section is constituted of metagabbro mylonitic clasts. In that zone, atoll garnets $(50-300 \mu \mathrm{m})$ are very abundant $(\approx 75 \%)$ and associated with deep green omphacite - optically zoned - often smaller than $100 \mu \mathrm{m}(\approx 15 \%)$ and small amalgamated rutile grains (Fig. 2b). Omphacite is found as individual crystals and included in garnet. The sample shows also a small zone of eclogitic matrix mostly ( $>70 \%$ ) composed of omphacite crystals ranging between $800 \mu \mathrm{m}$ and $1.5 \mathrm{~mm}$, associated with garnet porphyroblasts containing omphacite and rutile inclusions. Apatite and lawsonite pseudomorphs are also observed in the matrix. Two types of veins, T1 and T2, are found: $\mathrm{T} 1$ is composed of abundant prismatic omphacite crystals up to $2.5 \mathrm{~mm}$ and lawsonite pseudomorphs. The T2 type contains garnet and omphacite (Fig. 2c).

Sample SE1416B originates from the garnetclinopyroxene-bearing amphibolitic sole of the Semail ophiolite (Oman). This sample is a rodingite part of the series sampled and described by Soret et al. (2017). Rodingites are the product of hydrothermal alteration of the mafic rocks linked to devolatilization of marbles from the metamorphic sole. The sample SE1416B shows a rich diversity of min- 
Table 1. Mineral occurrences in the samples and associated peak metamorphic conditions.

\begin{tabular}{llrlcccccl}
\hline Sample & Type & $P(\mathrm{kbar})-T\left({ }^{\circ} \mathrm{C}\right)$ & Reference & Grt & Cpx & Ep & Ap & Amp & Other \\
\hline MA1438 & Amphibolite & $10-850$ & Dubacq et al. (2019) & X & X & X & X & X & Qz, Pl \\
MA1435 & Amphibolite & $10-850$ & Dubacq et al. (2019) & X & X & X & X & X & Pl \\
L3515 & Eclogite & $26-550$ & Locatelli (2017) & X & X & X & X & X & Rt \\
SE1416B & Rodingite & $7-650$ & Soret et al. (2017) & X & X & X & X & & Mel, Zr, Wol, Cal, Sp \\
\hline
\end{tabular}
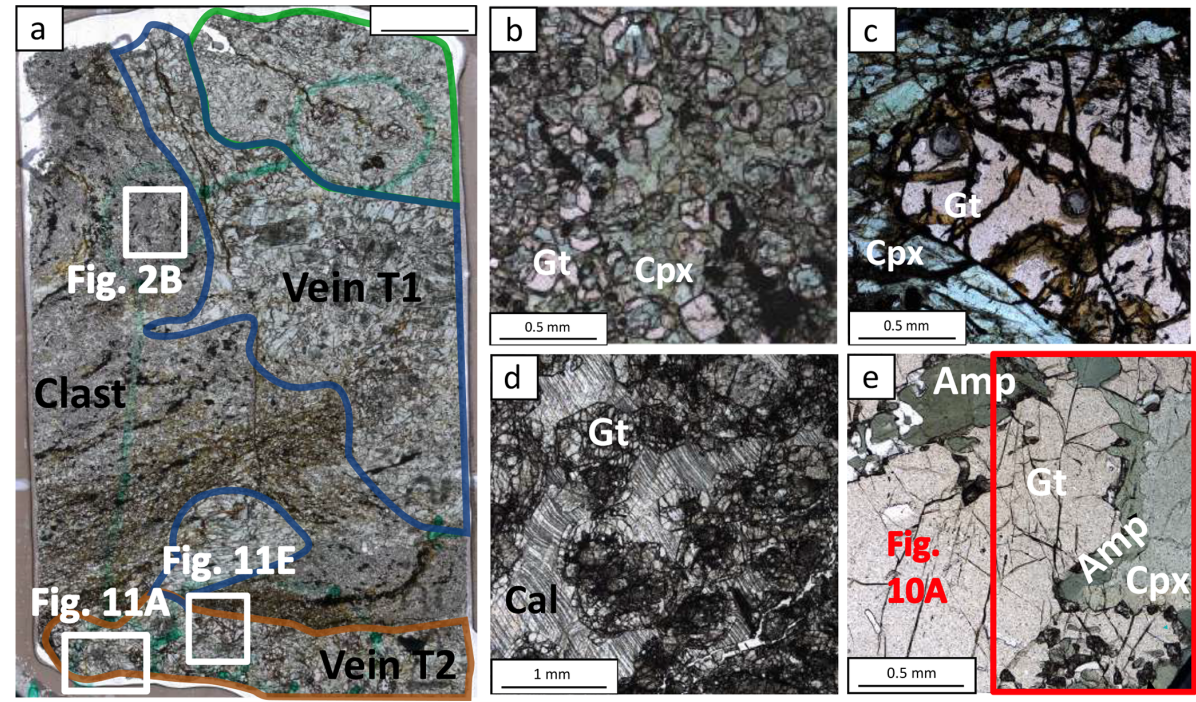

Figure 2. Optical microscope photographs of the samples. (a, b, c) Sample L3515, with veins highlighted. White rectangles show area selected for element mapping; (b) atoll garnets; (c) garnet and omphacite from the T2 vein. (d) Rodingite sample SE1416B: garnet crystals (with hydrogrossular-rich rim) surrounded by calcite. (e) Sample MA1438 with garnet-amphibole-clinopyroxene assemblage. The red box indicates the zone used for element mapping (Fig. 10a).

erals including wollastonite, calcite, clinopyroxene, garnet, titanite, apatite and epidote (Table 1). Clinopyroxene and calcite constitute more than $50 \%$ of the sample. Variably sized garnet is present $(\approx 15 \%-20 \%$ of the sample). Small garnets surrounded by large calcite crystals are locally observed with a rim enriched in hydrogrossular component (Fig. 2d).

\subsection{Analytical techniques}

Samples have been analysed by electron probe microanalyzer (EPMA) after optical microscopy. Analyses were carried out with Cameca SX50 and SX100 instruments at CAMPARIS (Sorbonne Université, Paris, France). Analytical conditions were tuned for low detection limits of $\mathrm{Cr}$ for point measurements in wavelength-dispersive spectroscopy (WDS) acquisition mode with $40 \mathrm{nA}$ beam current, $20 \mathrm{keV}$ acceleration voltage and three spectrometers analysing $\mathrm{Cr}$, allowing an average detection limit of $120 \mathrm{ppm}$ (for $\mathrm{Cr}$ ). Albite (Na), diopside $(\mathrm{Mg}, \mathrm{Si}, \mathrm{Ca})$, orthoclase $(\mathrm{Al}, \mathrm{K}), \mathrm{Fe}_{2} \mathrm{O}_{3}(\mathrm{Fe}), \mathrm{MnTiO}_{3}$ (Mn, Ti) and $\mathrm{Cr}_{2} \mathrm{O}_{3}(\mathrm{Cr})$ were used for standardization of elements in brackets. For element maps, $\mathrm{Cr}$ has been measured with high beam current (299 nA) and a detection limit of about $25 \mathrm{ppm}$. Compositional maps were quantified with the manufacturer's software (with the PAP method of Pouchou and Pichoir, 1991, as for point measurements) and processed with in-house software. Structural formulae were calculated on the basis of 12 oxygen atoms for garnet and 6 oxygen atoms for clinopyroxene. Particular attention has been paid to avoiding micro-inclusions that can trap ions like $\mathrm{Cr}^{3+}$ (Yang and Rivers, 2001). Representative point analyses are provided in Table A1.

\section{Results}

\subsection{Mineral structures and strain}

A list of computed cell parameters and volumes is given in Table 2 for endmembers; solid solutions with a Cr defect for CrGrs, CrPrp and CrJd; and the Cr-rich counterparts with $\mathrm{Al}$ defect AlUv, AlKno and AlKos. A synthetic table of the main computations carried out for all generated cells and supercells is also provided in the Supplement (Table S1). Experimental determinations from Smyth and McCormick (1995) are given for comparison. Overestimations of cell volumes 
by the B3LYP functional are observed but remain small. Deviations from XRD measurements are below $1.5 \%$ for cell parameters and comprised between $2.6 \%$ and $3.3 \%$ for volumes. It is noteworthy that the formalism used for calculations of exchange reactions and partition coefficients will cancel out systematic errors.

The deformation $\varepsilon$ of cation-oxygen bonds after incorporation of a $\mathrm{Cr}$ defect and relaxation of the structure has been computed from the initial ( $L_{\mathrm{i}}$, before defect incorporation) and final $\left(L_{\mathrm{f}}\right.$, with defect) interatomic distances:

$\varepsilon=\frac{L_{\mathrm{f}}-L_{\mathrm{i}}}{L_{\mathrm{i}}} \cdot 100$.

Figure $3 \mathrm{a}$ shows the displacement of atoms around the defect after the $\mathrm{Al}^{3+}=\mathrm{Cr}^{3+}$ exchange. Results are presented for the largest lattices of aluminous garnet endmembers only - grossular and pyrope - for readability. Computations in jadeite and chromiferous endmembers show similar variations with similar conclusions. Overall, a rapid non-linear decrease in the displacement is observed away from the $\mathrm{Cr}$ atom, reaching values below $0.01 \AA$ about $5 \AA$ away from the defect. This is consistent with relaxation being almost entirely accommodated over that distance. Deformation is shown in terms of bond strain (Fig. 3c) and angle variations (Fig. 3b). The strain patterns in all garnet types appear very similar with small differences, with strain being mostly accommodated by the two first neighbours. Greater strain is observed for pyroxene endmembers. Bond strain of pyrope, grossular and jadeite are compared (Fig. 3c) for primitive cell $S_{1}$ and quadruple supercell $S_{4}$. For both garnet types, $\mathrm{Cr}-\mathrm{O}$ bonds undergo the strongest strain (about $3.5 \%$ for pyrope and $3.2 \%$ for grossular). The strain at about $10 \AA$ - corresponding to the size of their primitive cell - is higher for $S_{1}$ than for $S_{4}$, highlighting interaction of defects. Small differences in relaxation are noted between and within mineral groups. Close to the defect (first four neighbours), pyrope shows more strain than grossular, in terms of bond lengths and angular strain (Fig. 3b): Cr-O-Si angle strain is almost twice larger in pyrope $(\approx 1.6 \%)$ than in grossular. In comparison, $\mathrm{O}-\mathrm{Si}-\mathrm{O}$ is more strained in $\mathrm{Cr}$-rich jadeite - almost $1.0 \%$.

Figure 4 illustrates bond strains in jadeite and grossular in the vicinity of a $\mathrm{Cr}$ defect. Even though the exchange of $\mathrm{Al}^{3+}$ for the bigger ion $\mathrm{Cr}^{3+}$ induced stretching of the bonds directly linked to the defect, relaxation is also accommodated by shortening of neighbouring bonds. In grossular, bond strain is symmetric around the defect but not radial in the sense of continuum mechanics (Fig. 4a). $\mathrm{Cr}-\mathrm{O}$ bonds are affected by stretching $(\approx 3 \%)$ and neighbouring $\mathrm{Si}-\mathrm{O}$ bonds are shortened by about $0.3 \%$. Most of the deformation is accommodated by the first two neighbours of the defect. The chain structure of jadeite displays a more distributed and complex strain (Fig. 4b). $\mathrm{Cr}-\mathrm{O}$ bonds are stretched up to about $4.5 \%$, not symmetrically. As for grossular, $\mathrm{Cr}^{3+}=$
$\mathrm{Al}^{3+}$ exchange also induced shortening of some $\mathrm{Si}-\mathrm{O}$ and Al-O bonds.

Importantly, the replacement of $\mathrm{Al}$ by $\mathrm{Cr}$ in the octahedral site induces stretching of the adjacent dodecahedral site (Fig. 5 and Table 2). Cation-oxygen bonds in the dodecahedral site are more strained in CrPrp than in CrGrs (up to $\approx 1 \%$ stretching and $\approx 0.5 \%$ shortening). Overall, the Ca site (CrGrs) increases by $0.32 \%$ when the $\mathrm{Mg}$ site (CrPrp) increases by $0.16 \%$, with both values being consistent with the cell volume increase after incorporation of $\mathrm{Cr}$ (Smyth and Bish, 1988, reported that the $\mathrm{X}$ site is $2.5 \%$ smaller in grossular than in uvarovite). The $\mathrm{Na}$ site in jadeite is more strained than garnet sites with a volume increase of $2.1 \%$ and up to $2 \%$ bond stretching and $0.9 \%$ compression.

\subsection{Energy and volume variations}

Solid solutions between $\mathrm{Al}$ and $\mathrm{Cr}$ endmembers show increasing volume with $\mathrm{Cr}$ content, consistent with the bigger ionic radius of $\mathrm{Cr}^{3+}$ (Shannon, 1976). The increase is essentially linear. Excess volumes are not zero but are all small (Fig. 6a): up to about $-0.03 \mathrm{~cm}^{3}$ p.f.u. for jadeitekosmochlor (i.e. less than $0.05 \%$ of the jadeite cell volume p.f.u.) and below about $-0.03 \mathrm{~cm}^{3}$ p.f.u. for grossularuvarovite and pyrope-knorringite (below about $0.03 \%$ of cell volume p.f.u. in both cases). For garnet, the trend is slightly dissymmetric, with more variability observed near aluminous endmembers (low $\mathrm{Cr}$ content). Pyroxene excess volumes are generally negative and follow comparable trends. Excess enthalpies are also small, lower than $0.05 \mathrm{~kJ} \mathrm{~mol}^{-1}$ p.f.u. Excess enthalpies tend to zero close to the endmembers, consistent with trace element behaviour and proper convergence of calculations during relaxation. The grossular-uvarovite solution has the largest excess enthalpy (Fig. 6b).

Small excess volumes show that the strain fields of defects do not interact and not an absence of strain. The volumes of the Y site (where defects are incorporated) and of their first neighbouring $\mathrm{X}$ site are provided in the Supplement (Table S1 and Fig. S1). Calculations for the largest lattices, where defects are most diluted, have the smallest excess volumes per formula unit but show the largest strain for the defect $\mathrm{Y}$ site. In $\mathrm{Cr}$-doped grossular, this shows that relaxation takes place around the whole $\mathrm{Cr}$ defect site, itself relatively undeformed compared to the $\mathrm{Cr}$ site of uvarovite, and vice versa for $\mathrm{Al}$ incorporation in uvarovite. The volume of the $\mathrm{X}$ site is little affected, as some bonds are stretched, some bonds are shortened and polyhedra are tilted during strain accommodation (Figs. 4 and 5).

\subsection{Theoretical partitioning of $\mathrm{Cr}$}

Figure 7 shows calculated defect energies along the binary solid solutions investigated. The difference between garnet and clinopyroxene defect energies - for the same $\mathrm{Cr}$ propor- 
Table 2. Cell parameters and volumes computed with CRYSTAL17 compared to data from Smyth and McCormick (1995) given in brackets. $\mathrm{Al}-\mathrm{O}, \mathrm{Cr}-\mathrm{O}$ and $\mathrm{Si}-\mathrm{O}$ bond lengths are also provided. Computed $\mathrm{Cr}-\mathrm{O}$ bond lengths are given in italic.

\begin{tabular}{|c|c|c|c|c|c|c|c|c|c|}
\hline & \multirow[b]{2}{*}{$\begin{array}{r}\text { Atoms per } \\
\text { cell }\end{array}$} & \multicolumn{3}{|c|}{$a, b, c$ cell parameters (in $\AA$ ) } & \multirow[b]{2}{*}{$\begin{array}{r}\text { Cell volume } \\
\qquad\left(\AA^{3}\right)\end{array}$} & \multicolumn{2}{|c|}{ Bonds (in $\AA$ ) } & \multicolumn{2}{|c|}{ X-site volume (in $\AA$ ) and strain (in \%) } \\
\hline & & $\begin{array}{r}a \\
(\text { vs. XRD) }\end{array}$ & $\begin{array}{r}b \\
(\text { vs. XRD) }\end{array}$ & $\begin{array}{r}c \\
\text { (vs. XRD) }\end{array}$ & & $\mathrm{Al} / \mathrm{Cr}-\mathrm{O}$ & $\mathrm{Si}-\mathrm{O}$ & Calculated & $\begin{array}{r}\text { Strain after } \\
\text { exchange (in \%) }\end{array}$ \\
\hline Grs & 80 & $11.957(11.845)$ & $11.957(11.845)$ & $11.957(11.845)$ & 1709.5 (1661.9) & 1.9406 & 1.6621 & 22.04 & \\
\hline CrGrs & 80 & 11.976 & 11.976 & 11.976 & 1717.8 & 2.0026 & 1.6574 & 22.11 & 0.32 \\
\hline Prp & 80 & $11.551(11.452)$ & $11.551(11.452)$ & $11.551(11.452)$ & $1541.2(1501.9)$ & 1.9008 & 1.6492 & 18.55 & \\
\hline CrPrp & 80 & 11.571 & 11.571 & 11.571 & 1549 & 1.9682 & 1.6482 & 18.58 & 0.16 \\
\hline Jd & 20 & $9.549(9.423)$ & $8.636(8.564)$ & $5.286(5.223)$ & $414.55(401.85)$ & 1.8626 & 1.6081 & 25.01 & \\
\hline CrJd & 20 & 9.622 & 8.716 & 5.317 & 423.79 & 1.9461 & 1.6057 & 25.53 & 2.08 \\
\hline Uv & 80 & $12.117(11.988)$ & $12.117(11.988)$ & $12.117(11.988)$ & $1778.9(1722.8)$ & 2.0134 & 1.6601 & 22.59 & \\
\hline AlUv & 80 & 12.097 & 12.097 & 12.097 & 1770.1 & 1.9505 & 1.6602 & 22.51 & -0.35 \\
\hline Kno & 80 & 11.711 & 11.711 & 11.711 & 1606.3 & 1.9783 & 1.6513 & 18.95 & \\
\hline AlKno & 80 & 11.691 & 11.691 & 11.691 & 1598 & 1.9104 & 1.6496 & 18.92 & \\
\hline Kos & 20 & 9.705 (9.579) & $8.792(8.722)$ & $5.340(5.267)$ & $433.33(419.98)$ & 1.9522 & 1.6076 & 25.85 & \\
\hline AlKos & 20 & 9.623 & 8.716 & 5.317 & 423.83 & 1.8696 & 1.6098 & 25.30 & \\
\hline
\end{tabular}
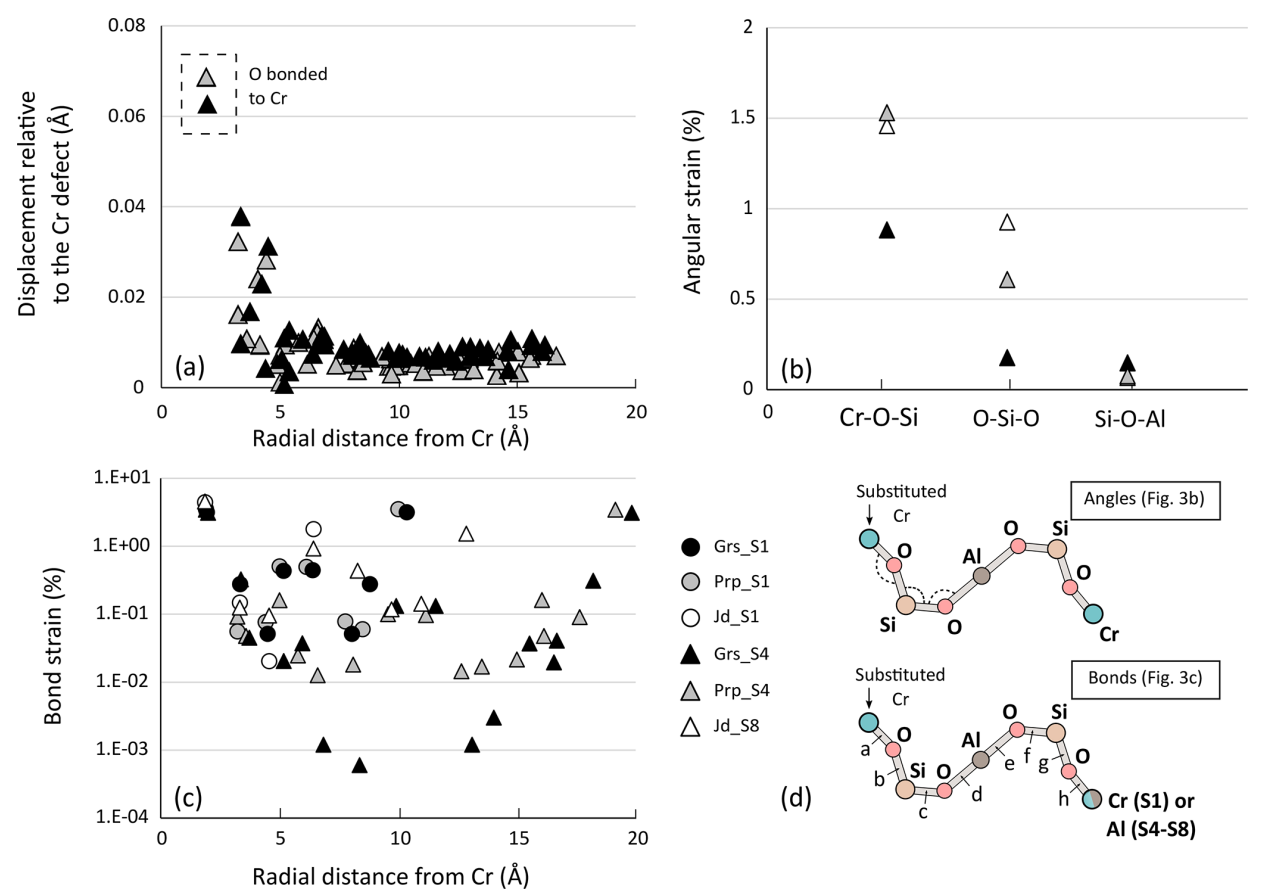

Figure 3. Computed strain in defect-doped minerals. Note that (c) is on a log scale; absolute values of bond strain are plotted. Triangles indicate supercells $S_{4}$ for garnets and $S_{8}$ for pyroxene, whereas circles are for smaller cells $S_{1}$. (a) Displacement of atoms in grossular and pyrope (in $\AA$ ) as a function of the radial distance to the defect (located at $0 \AA$ ). (b) Angular strain (in \%). Angles correspond respectively to $\mathrm{Cr}-\mathrm{O}-\mathrm{Si}, \mathrm{O}-\mathrm{Si}-\mathrm{O}$ and $\mathrm{Si}-\mathrm{O}-\mathrm{Al}$, as illustrated in (d). (c) Computed bond strain (in \%) in primitive cells $S_{1}$ and supercells $S_{4}$ as a function of the radial distance from the Cr defect (in $\AA$ ). (d) Sketch of angles and bonds strained after defect incorporation. Letters from "a" to " $h$ " correspond to the successive bonds.

tion, as shown on the $X$ axis - gives the Gibbs free energy of the exchange reactions (Reactions R3, R4, R5, R6). Comparing results obtained for garnet supercells $S_{2}(1.4 \mathrm{wt} \% \mathrm{Cr}$ in CrGrs, $1.6 \mathrm{wt} \%$ for CrPrp) and $S_{4}(0.7 \mathrm{wt} \% \mathrm{Cr}$ in $\mathrm{Cr}-$ Grs, $0.8 \mathrm{wt} \%$ for CrPrp), defect energies stabilize around $1 \mathrm{wt} \% \mathrm{Cr}$. The Gibbs free energy of reaction is estimated from the largest supercells where Cr dilution is highest $\left(S_{4}\right.$ for garnets and $S_{16}$ for clinopyroxene). The value for $\Delta G_{\mathrm{r}}{ }^{\circ} 3$
(Grs-Jd exchange) is negative with $\Delta G_{\mathrm{r}}{ }^{\circ}=-7 \mathrm{~kJ} \mathrm{~mol}^{-1}$, whereas $\Delta G_{\mathrm{r}}{ }^{\circ} 4$ (Prp-Jd exchange) is positive with $\Delta G_{\mathrm{r}}{ }^{\circ} 4=$ $22 \mathrm{~kJ} \mathrm{~mol}^{-1}$. In other words, calculations show that at equilibrium $\mathrm{Cr}$ is more favourably incorporated in grossular than in jadeite and more favourably incorporated in jadeite than in pyrope, in agreement with estimations of Dubacq and Plunder (2018) and experimental trends of van Westrenen et al. (2003). The value of $\Delta G_{\mathrm{r}}{ }^{\circ} 5$ (Uv-Kos exchange) is 


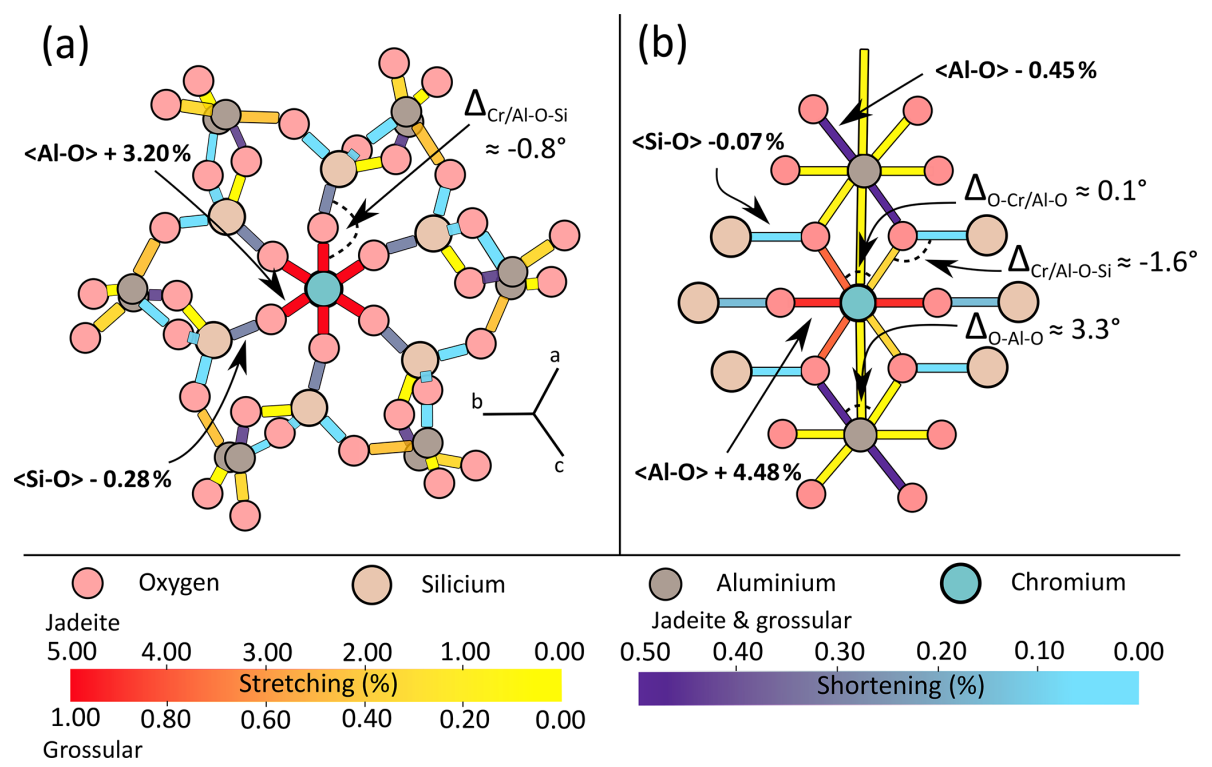

Figure 4. Bond strain in Cr-doped grossular and jadeite. Strain is expressed in percent (\%), indicated for both minerals as stretching for positive values and shortening for negative values. (a) Bond strain in the grossular primitive cell after $\mathrm{Cr}^{3+}=\mathrm{Al}^{3+}$ substitution. (b) $\mathrm{Planar}^{3}$ representation of chromium's local environment in jadeite after $\mathrm{Cr}^{3+}=\mathrm{Al}^{3+}$ substitution.
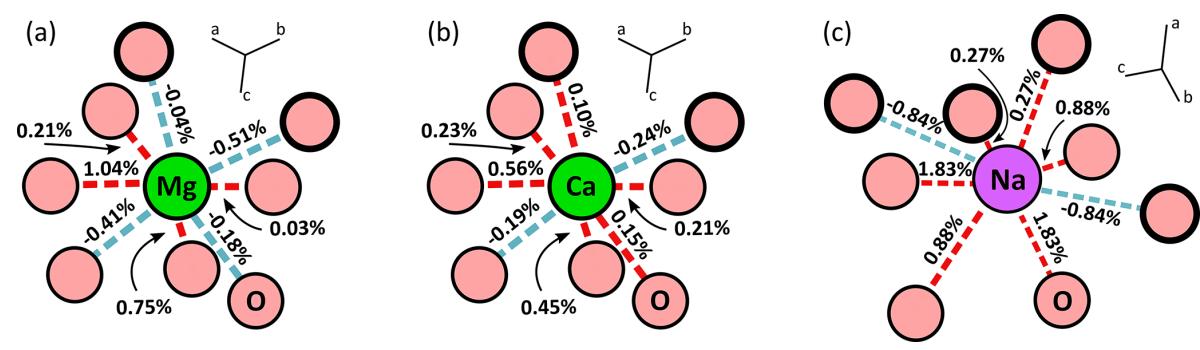

Figure 5. Bond strain (in \%) in the dodecahedral site neighbouring the defect site for Cr-doped pyrope (a), grossular (b) and jadeite (c). Strain is indicated in red for positive values (stretching) and blue for negative values (shortening). Oxygen atoms with bold circles are bonded to the $\mathrm{Cr}$ defect.

positive with $8 \mathrm{~kJ} \mathrm{~mol}^{-1}$, whereas that of $\Delta G_{\mathrm{r}}{ }^{\circ} 6$ (Kno-Kos exchange) is negative with $-25 \mathrm{~kJ} \mathrm{~mol}^{-1}$. Al incorporation is therefore more favourable to the $\mathrm{Mg}$-garnet chromiferous endmember than to the Ca-garnet chromiferous endmember.

Figure 8 shows partition coefficients estimated using Eq. (5) as a function of temperature. The $\mathrm{Cr}$ partition coefficient for grossular-jadeite and $\mathrm{Al}$ partition coefficient for knorringite-kosmochlor are greater than 1 , reflecting $\mathrm{Cr}$ partitioning in favour of Ca-garnet and $\mathrm{Al}$ partitioning in favour of Mg-garnet. On the contrary, $\mathrm{Cr}$ is predicted to partition in favour of jadeite for the pyrope-jadeite system, and $\mathrm{Al}$ is incorporated preferentially in kosmochlor for the uvarovitekosmochlor system.

\subsection{Distribution of $\mathrm{Cr}$ in natural samples}

Figure 9 shows the composition of garnet and clinopyroxene in the four samples. In samples MA1435 and MA1438 (granulite-facies amphibolite), garnet is a solid solution with high and variable almandine (Alm $\approx 40 \%-50 \%)$ and grossular contents ( $\mathrm{Grs} \approx 27 \%-40 \%$ ), as well as minor pyrope content of 20\%-30\% (Fig. 9a). The spessartine component is below $6 \%$. Estimated $\mathrm{Fe}^{3+}$ content is very low $(\leq 0.1$ a.p.f.u) and neglected thereafter. Zoning is observed for $\mathrm{Fe}, \mathrm{Mg}$ and $\mathrm{Mn}$, with generally increasing $\mathrm{Mn}$ and $\mathrm{Fe}$ from core to rims and decreasing $\mathrm{Mg}$ (Fig. 10a-e). Mn in symplectites increases toward the rim up to a maximum ring, followed by a thin Mn-poor and Ca-rich zone (Fig. 10d-e; see Dubacq et al., 2019, for details). The $\mathrm{Al}$ content varies within $1 \mathrm{wt} \% \mathrm{Al}_{2} \mathrm{O}_{3}$ and is lower in Cr-rich zones (Fig. 10b and c). The $\mathrm{Ca}$ content decreases globally from core to rims and increases again in the symplectites (Fig. 10d). Clinopyroxene (Fig. 9 b) is mainly of diopside type $(\mathrm{XCa} \approx 0.5-0.7)$ with a small jadeite component ( $\mathrm{XAl}=0.1-0.2)$. Radial zoning is observed for $\mathrm{Al}$ (from $6 \mathrm{wt} \% \mathrm{Al}_{2} \mathrm{O}_{3}$ in crystal cores to about $3 \mathrm{wt} \%$ in rims, Fig. 10c). In garnet and clinopyroxene, $\mathrm{Cr}$ content is very heterogeneous with sector zoning 

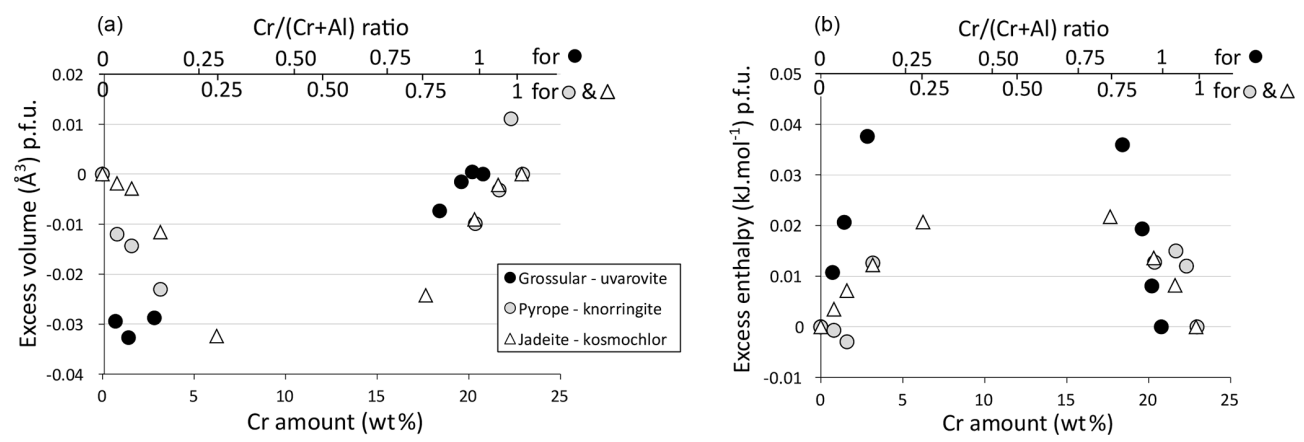

Figure 6. Excess quantities for garnet and clinopyroxene solid solutions as a function of the Cr amount. (a) Excess volume for jadeitekosmochlor (Jd-Kos), grossular-uvarovite (Grs-Uv) and pyrope-knorringite (Prp-Kno) solid solutions. (b) Excess enthalpy for jadeitekosmochlor (Jd-Kos), grossular-uvarovite (Grs-Uv) and pyrope-knorringite (Prp-Kno) solid solutions.

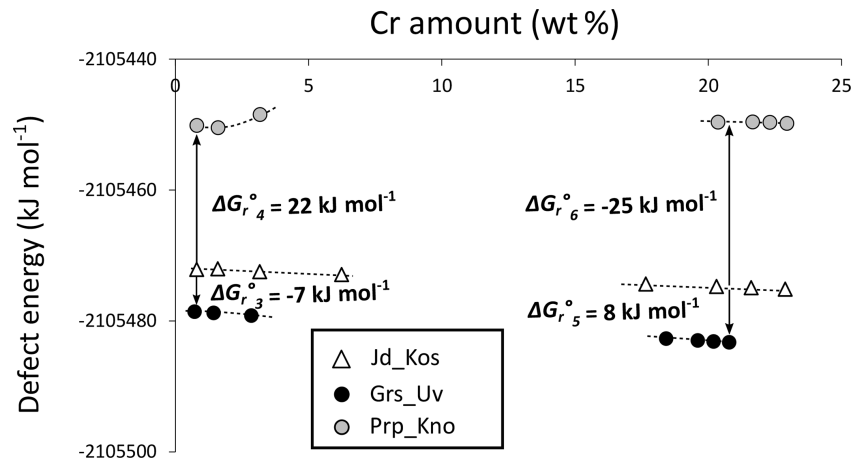

Figure 7. Computed defect energies (in $\mathrm{kJ} \mathrm{mol}^{-1}$ ) for garnet and clinopyroxene solid solutions as a function of the $\mathrm{Cr}$ amount (in wt \%). The Gibbs free energy of reaction is given for each exchange reaction.

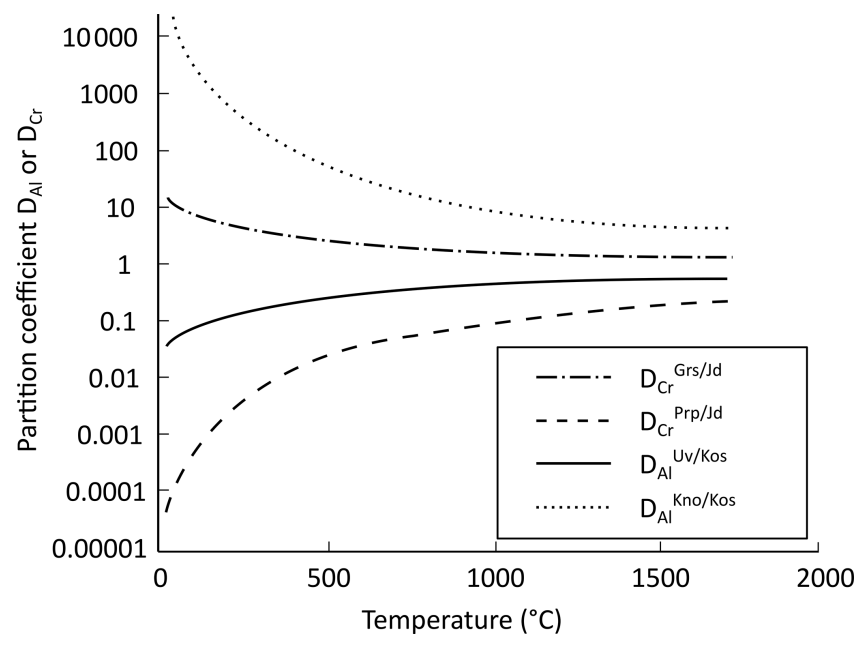

Figure 8. Evolution of calculated partition coefficients $D^{\mathrm{Grt} / \mathrm{Cpx}}$ of $\mathrm{Cr}$ and $\mathrm{Al}$ with temperature (in ${ }^{\circ} \mathrm{C}$ ) for grossular-jadeite, uvarovitekosmochlor, pyrope-jadeite and knorringite-kosmochlor exchange reactions.
Table 3. Apparent ( $D_{\text {app }}$ ) and computed ( $\left.D_{\text {theo }}\right)$ partition coefficients of $\mathrm{Cr}$ between garnet and clinopyroxene for each sample.

\begin{tabular}{lrrrr}
\hline Sample & Point & {$[\mathrm{Cr}]^{\mathrm{Grt}}(\mathrm{ppm})$} & $D_{\text {app }}$ & $D_{\text {theo }}$ \\
\hline \multirow{4}{*}{ MA1438 } & 1 & 771 & 3.6 & 1.6 \\
& 2 & 354 & 1.6 & \\
& 3 & 1492 & 6.8 & \\
\hline \multirow{4}{*}{ L3515 } & 1 & 5279 & 39 & 0.3 \\
& 2 & 1076 & 7.9 & \\
& 3 & 172 & 1.3 & \\
SE1416B & 1 & 127 & 6.5 & 138 \\
& 2 & 359 & 24 & \\
& 3 & 79 & 4.1 & \\
\hline
\end{tabular}

and thin Cr-rich or Cr-poor stripes cross-cutting major element zoning and grain boundaries. Chromium content ranges from below the detection limit $(<120 \mathrm{ppm})$ to more than $3000 \mathrm{ppm} \mathrm{Cr}_{2} \mathrm{O}_{3}$ in garnet and $700 \mathrm{ppm} \mathrm{Cr}_{2} \mathrm{O}_{3}$ in clinopyroxene. $\mathrm{Cr}$-rich domains are mostly found in garnet, but $\mathrm{Cr}$ rich zones also cross-cut grain boundaries and extend to the adjacent amphibole crystals (Fig. 10b). A negative correlation between $\mathrm{Al}$ and $\mathrm{Cr}$ is observed in some garnet crystals but not systematically. In garnet, $\mathrm{Cr}$-rich zones are also $\mathrm{Ca}$ rich in cores of amalgamated crystals. In clinopyroxene, $\mathrm{Cr}$ also displays sector and patchy zoning apparently unrelated to that of Al.

Garnet in the L3515 samples is Fe-rich and Ca-poor (XAlm $>60 \%$, XGrs $<20 \%$, XSps $<2 \%$, Fig. 9a). Radial zoning is observed for $\mathrm{Mg}$ and $\mathrm{Mn}$, with increasing $\mathrm{Mg}$ (from $\approx 4.5$ to $6.5 \mathrm{wt} \% \mathrm{MgO}$ ) and decreasing $\mathrm{Mn}$ (from 0.6 to $0.1 \mathrm{wt} \% \mathrm{MnO}$ ). Clinopyroxene displays two main compositions corresponding to cores and rims, as described by Locatelli (2017). Cores are of diopside type with $\mathrm{CaO}$ content between 10.1 and $15.6 \mathrm{wt} \%$ and $\mathrm{MgO}$ content between 6.4 and $9 \mathrm{wt} \%$. The jadeite component increases from core to rim, from $\approx 8.5$ to $\approx 10.3 \mathrm{wt} \% \mathrm{Al}_{2} \mathrm{O}_{3}$ and from $\approx 8.6$ to $\approx 9.6 \mathrm{wt} \% \mathrm{Na}_{2} \mathrm{O}$ (Fig. 11i and $\mathrm{j}$ ). There is a marked negative 
(a) Garnet

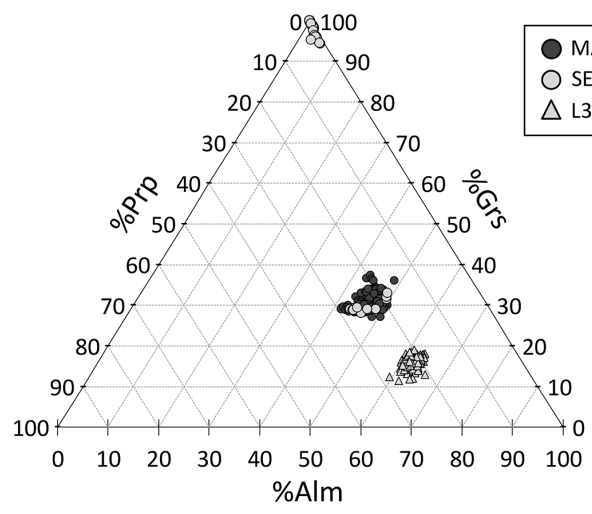

(b) Clinopyroxene

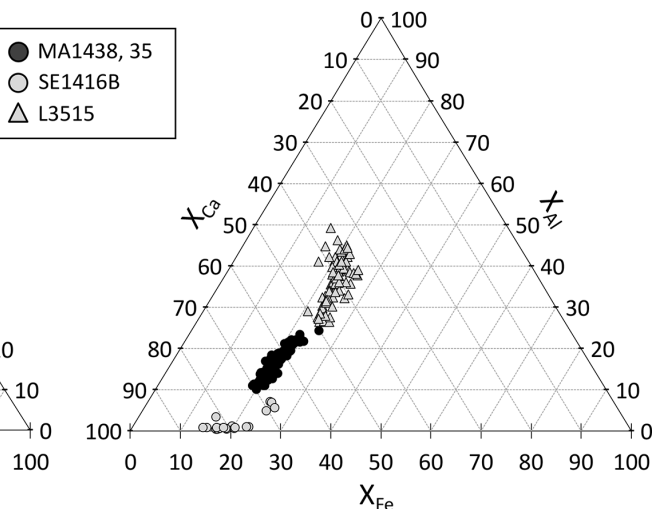

Figure 9. Garnet and clinopyroxene compositions for the present samples. (a) Garnet composition is shown as a function of grossular, pyrope and almandine content. (b) Clinopyroxene composition.
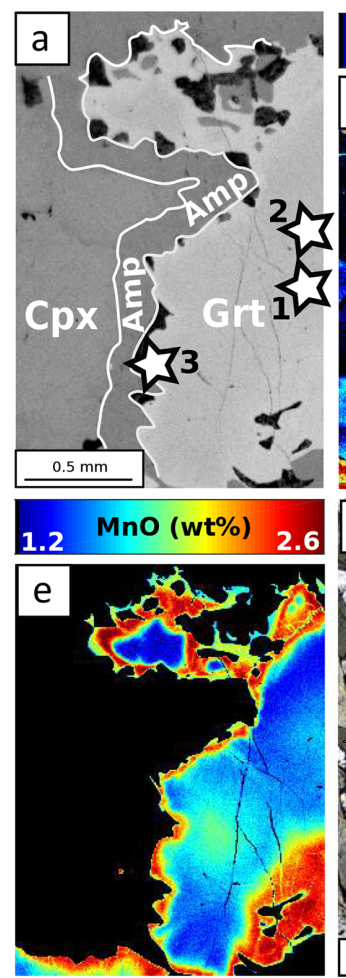
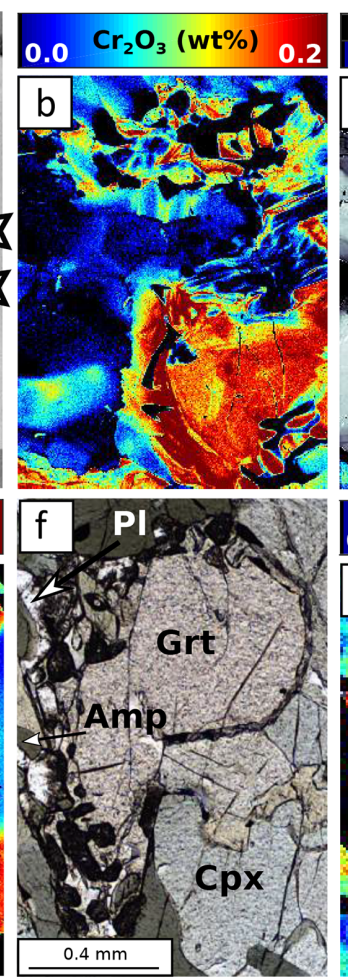
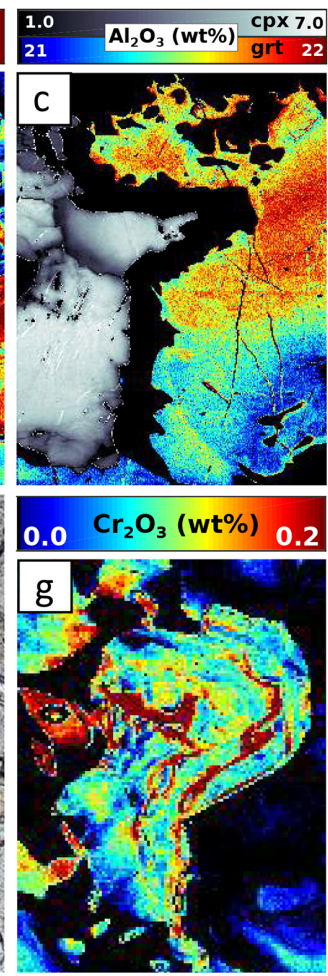
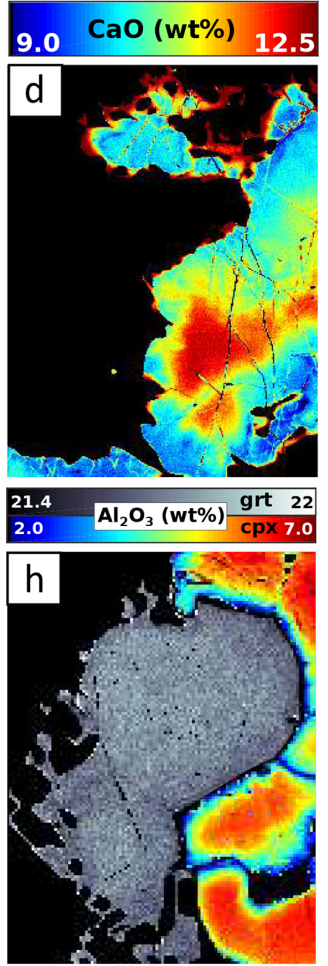

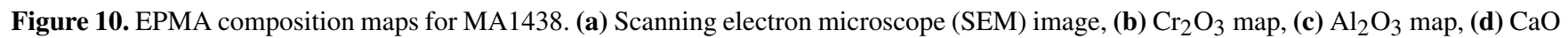
map and (e) $\mathrm{MnO}$ map correspond to the area highlighted in Fig. 2e. Stars indicate point analyses selected to estimate apparent partition coefficients reported in Table 3. (f) Microphotograph of zone 2. Corresponding compositional map for $\mathrm{Cr}_{2} \mathrm{O}_{3}(\mathbf{g})$ and $\mathrm{Al}_{2} \mathrm{O}_{3}(\mathbf{h})$ in garnetclinopyroxene-amphibole.

correlation between $\mathrm{Al}$ and $\mathrm{Cr}$, with $\mathrm{Cr}$-rich, $\mathrm{Al}$-poor sectors (Fig. 11). As for previous samples, $\mathrm{Ca}$ and $\mathrm{Al}$ display complex and patchy zoning. In Fig. 11g, the Cr-rich zone follows the garnet-clinopyroxene boundary. Alternations of thin $\mathrm{Cr}$ rich and Cr-poor bands are also observed, with Cr- and Caenriched bands cross-cutting the radial zoning displayed by major elements (Fig. $11 \mathrm{~b}$ and d). In clinopyroxene, $\mathrm{Cr}_{2} \mathrm{O}_{3}$ content reaches $0.4 \mathrm{wt} \%$ but is below the detection limit for other parts of the crystals (Fig. 11b and h). Positive and negative correlations between $\mathrm{Al}$ and $\mathrm{Cr}$ are found in this sample. Some Cr- and Al-poor zones are also Na-poor and $\mathrm{Ca}-$ and Mg-rich (Fig. 11h, i and j).

In sample SE1416B, garnet is Ca-rich and contains very little $\mathrm{Mg}$ (Fig. 9a). The $\mathrm{Ca}$ enrichment reflects incorpora- 

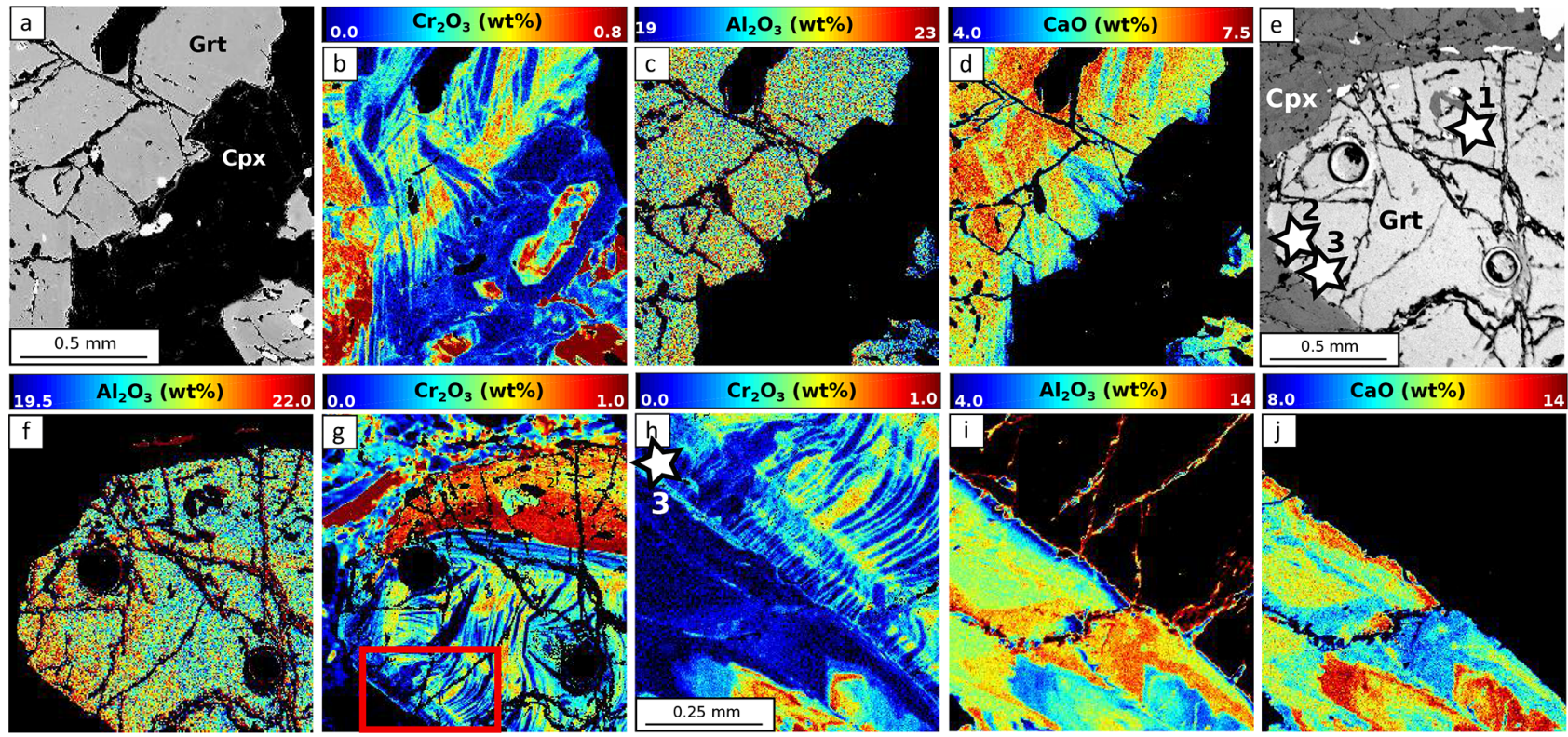

Figure 11. EPMA composition maps for L3515. The area imaged in (a) (SEM image) has been mapped for its $\mathrm{Cr}_{2} \mathrm{O}_{3}(\mathbf{b}), \mathrm{Al}_{2} \mathrm{O}_{3}(\mathbf{c})$ and $\mathrm{CaO}$ (d) content. Image (e) (SEM) shows the area mapped for $\mathrm{Al}_{2} \mathrm{O}_{3}$ (f) and $\mathrm{Cr}_{2} \mathrm{O}_{3}$ (g). Maps shown in (h) for $\mathrm{Cr}_{2} \mathrm{O}_{3}$, (i) for $\mathrm{Al}_{2} \mathrm{O}_{3}$ and (j) for $\mathrm{CaO}$ are close-up maps of the area shown in red in (g). Stars indicate point analyses used to estimate apparent partition coefficients reported in Table 3. The $\mathrm{NaO}$ map (not shown) shows similar variations to that of $\mathrm{Al}_{2} \mathrm{O}_{3}$, as for $\mathrm{MgO}$ and $\mathrm{CaO}$.

tion of grossular - and to a smaller extent hydrogrossular - components. Radial, successive zoning patterns are found for all analysed elements (Fig. 12). Crystal cores are globally enriched in $\mathrm{Al}$ and $\mathrm{Ca}$ and are poor in $\mathrm{Mn}$ and $\mathrm{Fe}$. The oscillation-like zone displays progressive $\mathrm{Al}$ and $\mathrm{Ca}$ decrease with $\mathrm{Fe}$ and $\mathrm{Mn}$ increase. The hydrogrossular component increases at the rim. Contrary to other samples, Cr shows successive zoning negatively correlated with Al. Clinopyroxene is of diopside type, with $\mathrm{XCa} \geq 70 \%$ (Fig. 9b). Epidote displays an allanite-rich core which decreases towards the rim enriched in pistacite component.

Figure $13 \mathrm{c}$ shows correlations between $\mathrm{Cr}^{3+}$ and $\mathrm{Al}^{3+}$ in garnet from all samples. In L3515, which has the highest concentration in $\mathrm{Cr}$, a well-defined negative correlation is observed between $\mathrm{Al}$ and $\mathrm{Cr}$, consistent with $\mathrm{Cr}^{3+}=\mathrm{Al}^{3+}$ exchange. No trend is observed for the other samples as $\mathrm{Cr}$ is too diluted to significantly modify Al concentration.

Given the disparity of $\mathrm{Cr}$ concentrations in garnet of the four samples, apparent partition coefficients $D_{\text {app }}$ have been estimated on selected garnet point analyses, as indicated by the stars in the figures. The amount of $\mathrm{Cr}$ in clinopyroxene has been considered homogeneous, excluding analyses from the most-Cr-rich sectors. Table 3 reports the obtained $D_{\text {app }}$, in comparison with the theoretical partition coefficient $D_{\text {theo }}$ computed for each sample using Eq. (5).

\section{Interpretations and implications}

\subsection{Chemical control on $\mathrm{Cr}$ partitioning and strain accommodation}

The $\mathrm{Al}^{3+}=\mathrm{Cr}^{3+}$ exchange is the preponderant mechanism for $\mathrm{Cr}^{3+}$ incorporation in garnet and clinopyroxene. However, concomitant cation exchange is possible. For garnet in the MA1535, MA1538 and L3515 samples, the coupled substitution ${ }^{\mathrm{VIII}} \mathrm{Ca}^{2+}+{ }^{\mathrm{VI}} \mathrm{Cr}^{3+}={ }^{\mathrm{VIIII}} \mathrm{Mg}^{2+}+{ }^{\mathrm{VI}} \mathrm{Al}^{3+}$ is observed in part of the samples, consistent with the positive correlation between $\mathrm{Cr}$ and $\mathrm{Ca}$ in composition maps (e.g. Fig. 11d). This mechanism was also proposed in previous studies (e.g. Wood and Kleppa, 1984; Griffin et al., 1999; Kopylova et al., 2000). It has been especially described in mantle rocks where it has been named "lherzolite trend" (Griffin et al., 1999). Similarly, Kopylova et al. (2000) proposed that the grossular component of garnet was dependent on $\mathrm{Cr}$ content, pressure and temperature in clinopyroxenebearing xenoliths from Jericho kimberlite, Canada.

In garnet and pyroxene, neither strain nor displacement are radial around defects. Instead, some bonds neighbouring defects are stretched, some bonds are shortened and polyhedra are tilted. This is in opposition to the lattice strain model (Blundy and Wood, 1994, among many others) as discussed by Dubacq and Plunder (2018). The contrasted accommodation of strain in garnet and jadeite is easily explained by differences in their crystal structures. Garnets are rigid nesosilicates: strain is more localized and limited compared to 

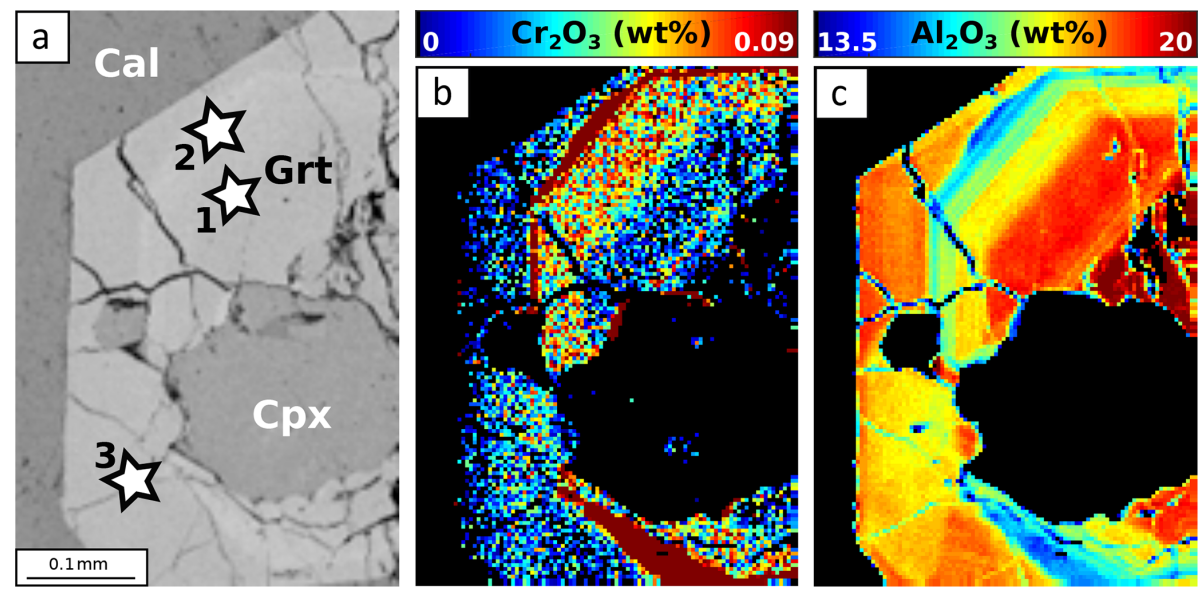

Figure 12. EPMA composition maps for SE1416B. Stars indicate point analyses used to estimate apparent partition coefficients reported in Table 3. (a) SEM image. (b) Composition map for $\mathrm{Cr}_{2} \mathrm{O}_{3}$ in garnet. (c) Composition map for $\mathrm{Al}_{2} \mathrm{O}_{3}$ in garnet.

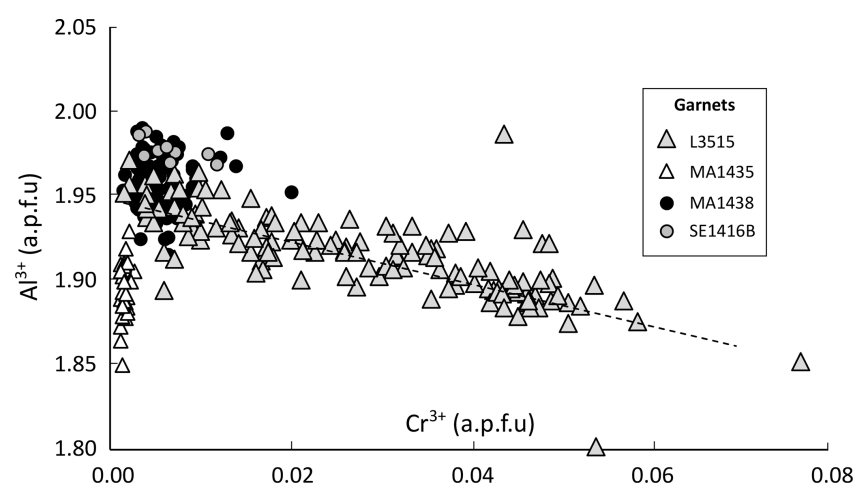

Figure 13. $\mathrm{Cr}-\mathrm{Al}$ correlation graph for garnet in all samples. The dashed line shows $1: 1$ exchange of $\mathrm{Cr}^{3+}$ and $\mathrm{Al}^{3+}$. Element concentrations are expressed in atoms per formula unit (a.p.f.u.).

jadeite. Polyhedral tilting is limited and bond length variations accommodate most of the strain in the vicinity of the defect. Jadeite is less rigid and densely packed than garnet, allowing more polyhedral tilting in addition to bond length variations.

Incorporation of $\mathrm{Cr}^{3+}$ mostly impacts the host octahedral site, but there is also strain in the dodecahedral site of the garnet and clinopyroxene endmembers. The $\mathrm{X}$ site expands due to $\mathrm{Cr}^{3+}$ incorporation, especially in grossular, in agreement with the positive correlation between $\mathrm{Cr}$ and $\mathrm{Ca}$ : presence of $\mathrm{Ca}$ in the $\mathrm{X}$ site may promote incorporation of $\mathrm{Cr}^{3+}$ by decreasing steric hindrance. Computed $D_{\text {theo }}$ coefficients display systematic opposite behaviour when comparing pyrope with grossular, with $\mathrm{Cr}^{3+}$ preferentially incorporated in grossular over jadeite and preferentially incorporated in jadeite over pyrope. This confirms the correlated behaviour of $\mathrm{Ca}$ and $\mathrm{Cr}$ is not restricted to mantle rocks.

In clinopyroxene, coupled mechanisms may also be proposed in addition to the likely dominant $\mathrm{Al}^{3+}=\mathrm{Cr}^{3+}$ sub- stitution. Unfortunately, EPMA measurements do not evidence any, due to very low amount of $\mathrm{Cr}$ in pyroxene. The Tschermak-type substitution ${ }^{\mathrm{IV}} \mathrm{Si}^{4+}+{ }^{\mathrm{VI}} \mathrm{Mg}^{2+}={ }^{\mathrm{IV}} \mathrm{Al}^{3+}$ $+{ }^{\mathrm{VI}} \mathrm{Cr}^{3+}$ has been proposed, by Urusov and Taran (2012), where $\mathrm{Cr}^{3+}$ does not substitute with $\mathrm{Al}^{3+}$ but with octahedral $\mathrm{Mg}^{2+}$. Similar coupled exchanges involving $\mathrm{Na}^{+}$may be proposed for clinopyroxene but are not observed here, yet $\mathrm{Na}^{+}$likely plays a role in clinopyroxene similar to $\mathrm{Ca}^{2+}$ in garnet. The modelled joined expansion of the $\mathrm{Na}$ and $\mathrm{Al}$ sites after $\mathrm{Cr}$ incorporation explains easier incorporation of trace $\mathrm{Cr}$ in jadeitic clinopyroxene. Incorporation of $\mathrm{Cr}$ in the $\mathrm{Mg}$ site coupled with that of $\mathrm{Na}$ in the $\mathrm{Ca}$ site of diopside has not been modelled here but could be a mechanism worth investigating at low $\mathrm{Cr}$ concentrations.

It follows that concentration of defects may be of key importance for the computation of realistic partition coefficients. This has not been modelled here but it is noted that studies report clustered defect contents in natural crystals (Peterman et al., 2019; Seydoux-Guillaume et al., 2019).

\subsection{Disequilibrium and role of kinetics}

Composition maps provide clear evidence of $\mathrm{Cr}$ disequilibrium, and comparison of theoretical and apparent partition coefficients allow us to estimate its extent for each sample. The theoretical partition coefficient of 0.3 computed for the L3515 sample predicts a Cr partitioning in favour of clinopyroxene, which can be understood by the higher proportion jadeite in pyroxene and lower grossular content in garnet compared to the MA1438 and SE1416B samples. Apparent partition coefficients are hugely variable but generally much higher than the theoretical value. The Cr-rich sectors in garnet are drastically out of equilibrium with pyroxene, as for the Cr-poor garnet. Similarly, enriched patches in the MA1418 sample are out of equilibrium, showing preferential distribution in garnet. Some areas around the Cr-rich patches 
have $\mathrm{Cr}$ content consistent with equilibrium partitioning with clinopyroxene. As a result, $\mathrm{Cr}$ displays here only localized partitioning at equilibrium between garnet and clinopyroxene, despite the high temperature conditions $\left(\approx 850^{\circ} \mathrm{C}\right)$ promoting diffusivity in metamorphic fluids, grain boundaries and intracrystalline diffusion. In the SE1416B sample, $\mathrm{Cr}$ partitioning is predicted to be largely in favour of garnet $\left(D_{\text {theo }}=138\right)$. Although measurements show $\mathrm{Cr}$ is preferentially incorporated in garnet, concentrations are lower than predicted. This is partly due to the very low $\mathrm{Cr}$ content of clinopyroxene (close to or below the detection limit) complicating its measurement. Evolving composition of fluids during garnet growth is shown by changing $\mathrm{Al}$ and $\mathrm{Cr}$ content (Fig. 12). Equilibrium with included clinopyroxene has therefore probably not been maintained during the growth of garnet.

Compositional mapping of Cr-rich areas cross-cutting radial zoning of major elements can not be explained as a consequence of crystallization at equilibrium. The metamorphic reactions leading to crystallization of garnet and clinopyroxene are mediated by diffusion of cations in fluids and along grain boundaries, feeding the growing crystals. Evidence shows that the mobility of $\mathrm{Cr}$ was reduced during garnet growth in all samples but SE1416B (marble), with the effective diffusivity of $\mathrm{Cr}$ lower than the garnet growth rate: homogenization of $\mathrm{Cr}$ around the growing crystals was much slower than crystal growth. In this view, Cr-rich sectors are interpreted as the remnants of former Cr-rich phases - likely a phyllosilicate for elongated prismatic shapes seen in the L3515 sample (Fig. 11g-h). Martin (2009) provides similar interpretation from $\mathrm{Cr}$ and $\mathrm{Y}$ mapping in garnet. This argues for interface-coupled dissolution-precipitation, a kinetically controlled phenomenon reported in previous studies (e.g. the stunning maps of minor elements in garnet by Ague and Axler, 2016). Additional kinetics effects may be invoked (see Reznitsky et al., 2011; Kohn, 2014). In particular for clinopyroxene, some crystal faces may show higher apparent partition coefficients due to electrostatic effects (see Dowty, 1976). Electrostatic effects on crystal faces may generate zoning cross-cutting radial patterns, as observed by Van Hinsberg et al. (2006) for sectorial and hourglass zoning in tourmaline. Radial zoning of $\mathrm{Cr}$ in garnet attests to $\mathrm{Cr}$ mobility and may record evolving fluid composition (Angiboust et al., 2014). In this case, the use of equilibrium partition coefficients is justified; however, presence of sectorial zoning and interface-coupled dissolution-precipitation precludes equilibrium modelling.

Therefore, interpretation of $\mathrm{Cr}$ zoning should account for small-scale features showing disequilibrium, then local equilibrium crystallization (on a scale reflecting mineral assemblages), and lastly possible opening of the system via fluids.

\section{Main conclusions}

Combined ab initio modelling and mapping of the $\mathrm{Cr}^{3+}$ distribution in garnet and clinopyroxene allow detailed understanding of incorporation mechanisms effectively taking place in metamorphic rocks.

$\mathrm{Ab}$ initio modelling allows reproducing trace element behaviour for the $\mathrm{Al}^{3+}=\mathrm{Cr}^{3+}$ substitution in garnet and clinopyroxene. Estimation of theoretical partition coefficients usefully combines with experimental petrology and measurements in natural rocks.

The $\mathrm{Cr}^{3+}=\mathrm{Al}^{3+}$ exchange is not a function of cation radius differences only. The local environment of the exchange site and the structural differences between clinopyroxene and garnet play a role in strain accommodation, impacting the partitioning of $\mathrm{Cr}$.

Kinetics is essential to explain $\mathrm{Cr}$ zoning in garnet and clinopyroxene, and departure from equilibrium may be estimated with observed deviation from theoretical partition coefficients. Slow crystalline diffusion, low diffusivity in fluids, and grain boundaries as well as electrostatic effects on crystal faces hamper reaching equilibrium.

Perspectives to this work include extension of the chemical system to divalent iron and application to other mineral assemblages. The results obtained here for $\mathrm{Cr}$ can probably be generalized to other relatively immobile trivalent trace elements such as Y (Martin, 2009) and other rare earths. Interface-coupled dissolution-precipitation in highgrade rocks (e.g. Ague and Axler, 2016) as well as electrostatic effects and clustering of defects are not in favour of using partition coefficients for geochemical modelling. Without going as far as Dowty (1976), who dismisses the use of clinopyroxene for thermobarometry on the ground of kinetic effects, measuring the distribution of trace elements when possible appears safer for correct interpretation. 


\section{Appendix A}

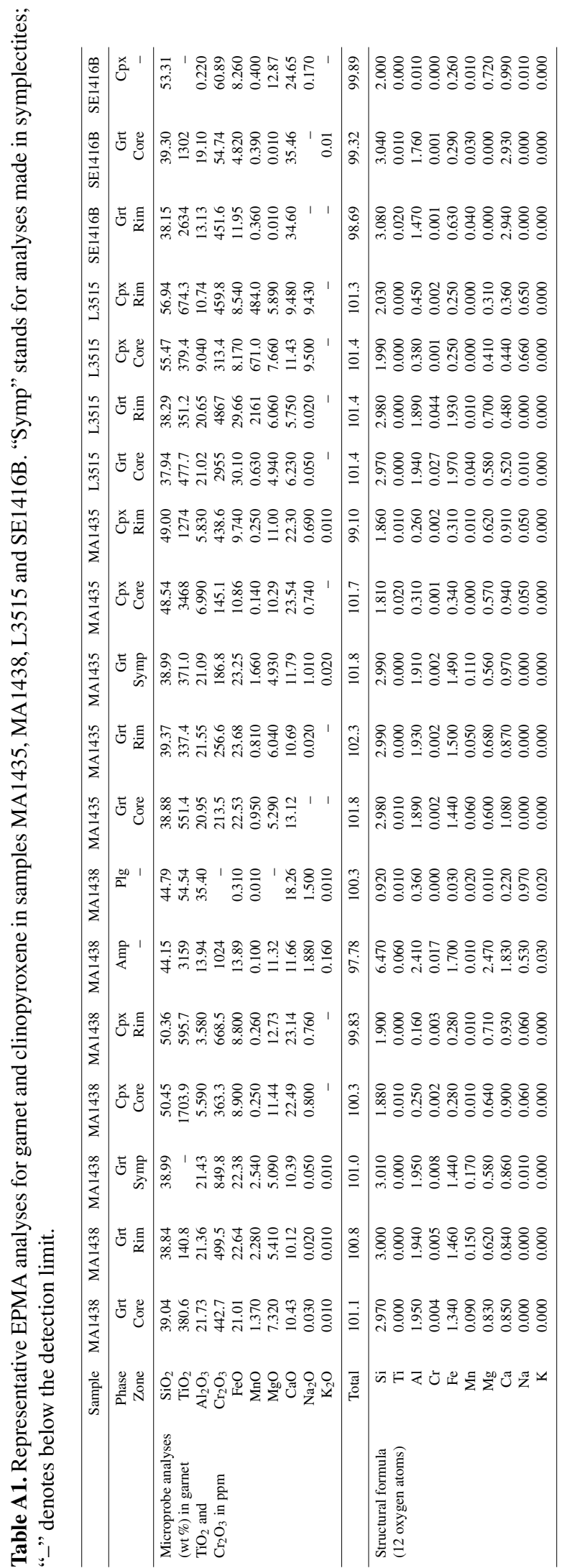


Code and data availability. Outputs generated using the CRYSTAL17 program are provided in CIF format in the Supplement.

Supplement. The supplement related to this article is available online at: https://doi.org/10.5194/ejm-32-387-2020-supplement.

Author contributions. The present manuscript was prepared with contributions from all co-authors. SF and BD worked on the natural samples and thermodynamic processing of computed data. YN, PD and SF performed the simulations with the CRYSTAL17 program.

Competing interests. The authors declare that they have no conflict of interest.

Acknowledgements. Many thanks are due to Nicolas Rividi, Michel Fialin (CAMPARIS, Sorbonne Université) and Omar Boudouma for their help and expertise with EPMA and SEM. The authors are indebted to Roberto Dovesi, Fabien Pascale, Simone Salustro and Marco De La Pierre for their precious help on CRYSTAL17 inputs. Computations have been made possible by using the MeSU calculation centre (ISCD) and the CINES centre. Two anonymous reviewers are gratefully acknowledged for their acute and constructive comments.

Review statement. This paper was edited by Alessandro Pavese and reviewed by two anonymous referees.

\section{References}

Ague, J. J. and Axler, J. A.: Interface coupled dissolutionreprecipitation in garnet from subducted granulites and ultrahigh-pressure rocks revealed by phosphorous, sodium, and titanium zonation, Am. Mineral., 101, 1696-1699, https://doi.org/10.2138/am-2016-5707, 2016.

Albarède, F. and Bottinga, Y.: Kinetic disequilibrium in trace element partitioning between phenocrysts and host lava, Geochim. Cosmochim. Ac., 36, 141-156, https://doi.org/10.1016/00167037(72)90003-8, 1972

Allan, N. L., Du, Z., Lavrentiev, M. Yu., Blundy, J. D., Purton, J. A., and van Westrenen, W.: Atomistic simulation of mineral-melt trace-element partitioning, Phys. Earth Planet. In., 139, 93-111, https://doi.org/10.1016/S0031-9201(03)00147-X, 2003.

Allègre, C. J., Treuil, M., Minster, J.-F., Minster, B., and Albarède, F.: Systematic use of trace element in igneous process, Contrib. Mineral. Petr., 60, 57-75, https://doi.org/10.1007/BF00372851, 1977.

Angiboust, S., Pettke, T., De Hoog, J. C. M., Caron, B., and Oncken, O.: Channelized Fluid Flow and Eclogite-facies Metasomatism along the Subduction Shear Zone, J. Petrol., 55, 883916, https://doi.org/10.1093/petrology/egu010, 2014.
Blundy, J. and Wood, B.: Prediction of crystal-melt partition coefficients from elastic moduli, Nature, 372, 452-454, https://doi.org/10.1038/372452a0, 1994.

Boutoux, A., Verlaguet, A., Bellahsen, N., Lacombe, O., Villemant, B., Caron, B., Martin, E., Assayag, N., and Cartigny, P.: Fluid systems above basement shear zones during inversion of pre-orogenic sedimentary basins (External Crystalline Massifs, Western Alps), Lithos, 206-207, 435-453, https://doi.org/10.1016/j.lithos.2014.07.005, 2014

Burns, R. G.: Crystal field effects in chromium and its partitioning in the mantle, in: Chromium: its Physicochemical Behavior and Petrologic Significance, edited by: Irvine, T. N., Pergamon, 857864, 1976.

Carlson, W. D., Pattison, D. R. M., and Caddick, M. J.: Beyond the equilibrium paradigm: How consideration of kinetics enhances metamorphic interpretation, Am. Mineral., 100, 16591667, https://doi.org/10.2138/am-2015-5097, 2015.

Carpenter, M. A., McKnight, R. E. A., Howard, C. J., Zhou, Q., Kennedy, B. J., and Knight, K. S.: Characteristic length scale for strain fields around impurity cations in perovskites, Phys. Rev. B, 80, 214101, https://doi.org/10.1103/PhysRevB.80.214101, 2009.

Chauvel, C., Lewin, E., Carpentier, M., Arndt, N. T., and Marini, J.-C.: Role of recycled oceanic basalt and sediment in generating the Hf-Nd mantle array, Nat. Geosci., 1, 64-67, https://doi.org/10.1038/ngeo.2007.51, 2008.

Chernoff, C. B. and Carlson, W. D.: Trace element zoning as a record of chemical disequilibrium during garnet growth, Geology, 27, 555-558, https://doi.org/10.1130/00917613(1999)027<0555:TEZAAR>2.3.CO;2, 1999.

De La Pierre, M. and Belmonte, D.: Ab initio investigation of majorite and pyrope garnets: Lattice dynamics and vibrational spectra, Am., Mineral., 101, 162-174, https://doi.org/10.2138/am2016-5382, 2016.

Dove, M. T., Thayaparam, S., Heine, V., and Hammonds, K. D.: The phenomenon of low Al-Si ordering temperatures in aluminosilicate framework structures, Am. Mineral., 81, 349-362, https://doi.org/10.2138/am-1996-3-409, 1996.

Dovesi, R., Orlando, R., Civalleri, B., Roetti, C., Saunders, V. R., and Zicovich-Wilson, C. M.: CRYSTAL: a computational tool for the ab initio study of the electronic properties of crystals, Z. Krist.-Cryst. Mater., 220, 571-573, https://doi.org/10.1524/zkri.220.5.571.65065, 2005.

Dovesi, R., Erba, A., Orlando, R., Zicovich-Wilson, C. M., Civalleri, B., Maschio, L., Rérat, M., Casassa, S., Baima, J., Salustro, S., and Kirtman, B.: Quantum-mechanical condensed matter simulations with CRYSTAL, WIREs Comput. Mol. Sci., 8, e1360, https://doi.org/10.1002/wcms.1360, 2018.

Dowty, E.: Crystal structure and crystal growth; II, Sector zoning in minerals, Am. Mineral., 61, 460-469, 1976.

Dubacq, B. and Plunder, A.: Controls on Trace Element Distribution in Oxides and Silicates, J. Petrol., 59, 233-256, https://doi.org/10.1093/petrology/egy027, 2018.

Dubacq, B., Soret, M., Jewison, E., and Agard, P.: Early subduction dynamics recorded by the metamorphic sole of the Mt. Albert ophiolitic complex (Gaspé, Quebec), Lithos, 334-335, 161-179, https://doi.org/10.1016/j.lithos.2019.03.019, 2019.

Geiger, C. A.: Thermodynamics of $\left(\mathrm{Fe}^{2+}, \mathrm{Mn}^{2+}, \mathrm{Mg}, \mathrm{Ca}_{3}-\right.$ $\mathrm{Al}_{2} \mathrm{Si}_{3} \mathrm{O}_{12}$ garnet: a review and analysis, Miner. Petrol., 66, 271299, https://doi.org/10.1007/BF01164497, 1999. 
Griffin, W. L., Fisher, N. I., Friedman, J., Ryan, C. G., and O’Reilly, S. Y.: Cr-Pyrope Garnets in the Lithospheric Mantle. I. Compositional Systematics and Relations to Tectonic Setting, J. Petrol., 40, 679-704, https://doi.org/10.1093/petroj/40.5.679, 1999.

Helmke, P. A. H.: Rare earths and other trace elements in Apollo 14 samples, in: Lunar and Planetary Science Conference Proceedings, USA, 1275-1292, 10-13 January 1972.

Hickmott, D. D. and Shimizu, N.: Trace element zoning in garnet from the Kwoiek Area, British Columbia: disequilibrium partitioning during garnet growth?, Contrib. Mineral. Petr., 104, 619630, https://doi.org/10.1007/BF01167283, 1990.

Hofmann, A. W.: Chemical differentiation of the Earth: the relationship between mantle, continental crust, and oceanic crust, Earth Planet. Sc. Lett., 90, 297-314, https://doi.org/10.1016/0012821X(88)90132-X, 1988.

John, T., Gussone, N., Podladchikov, Y. Y., Bebout, G. E., Dohmen, R., Halama, R., Klemd, R., Magna, T., and Seitz, H.-M.: Volcanic arcs fed by rapid pulsed fluid flow through subducting slabs, Nat. Geosci., 5, 489-492, https://doi.org/10.1038/ngeo1482, 2012.

Kohn, M.: Geochemical zoning in metamorphic minerals, in: Treatise on Geochemistry: The Crust, 2nd Edn., edited by: Holland, H. and Turekian, K., Elsevier, USA, 249-280, https://doi.org/10.1016/B978-0-08-095975-7.00307-7, 2014

Kopylova, M. G., Russell, J. K., Stanley, C., and Cookenboo, H.: Garnet from $\mathrm{Cr}-$ and Ca-saturated mantle: implications for diamond exploration, J. Geochem. Explor., 68, 183-199, https://doi.org/10.1016/S0375-6742(00)00004-2, 2000.

Lacivita, V., Mahmoud, A., Erba, A., D’Arco, P., and Mustapha, S.: Hydrogrossular, $\mathrm{Ca}_{3} \mathrm{Al}_{2}\left(\mathrm{SiO}_{4}\right)_{3-x}\left(\mathrm{H}_{4} \mathrm{O}_{4}\right)_{x}$ : An ab initio investigation of its structural and energetic properties, Am. Mineral., 100, 2637-2649, https://doi.org/10.2138/am-2015-5334, 2015.

Langer, K. and Andrut, M.: The crystal field concept in geosciences: Does the crystal field stabilization energy of $\mathrm{Cr}^{3+}$ rule its intercrystalline partition behaviour, Mineral spectroscopy: a tribute to Roger G. Burns, The Geochemical Society Special Publication, 29-40, 1996.

Langer, K., Platonov, A. N. and Matsyuk, S. S.: Local mean chromium-oxygen distances in $\mathrm{Cr}^{3+}$-centered octahedra of natural grossular-uvarovite garnet solid solutions from electronic absorption spectra, Z. Krist.-Cryst. Mater., 219, 272-277, https://doi.org/10.1524/zkri.219.5.272.32743, 2004.

Locatelli, M.: Eclogitic breccias from Monviso (W. Alps): structural, petrographic and geochemical evidence for multiple rupture stages at intermediate depths in subduction zones, $\mathrm{PhD}$ thesis, Paris 6, France, 280 pp., 2017.

Martin, A. J.: Sub-millimeter Heterogeneity of Yttrium and Chromium during Growth of Semi-pelitic Garnet, J. Petrol., 50, 1713-1727, https://doi.org/10.1093/petrology/egp050, 2009.

Morse, S. A.: Linear partitioning in binary solutions: A review with a novel partitioning array, Am. Mineral., 100, 1021-1032, https://doi.org/10.2138/am-2015-5056, 2015.

Ohashi, H.: The behaviour of $\mathrm{Cr}^{3+}$ ion in some silicates, The journal of the Japanese Association of Mineralogists, Petrologists and Economic Geologists, 75, 209-212, 1980.

Pabst, S., Zack, T., Savov, I. P., Ludwig, T., Rost, D., Tonarini, S., and Vicenzi, E. P.: The fate of subducted oceanic slabs in the shallow mantle: Insights from boron isotopes and light element composition of metasomatized blueschists from the Mariana forearc, Lithos, 132-133, 162-179, https://doi.org/10.1016/j.lithos.2011.11.010, 2012.

Pascale, F., Tosoni, S., Zicovich-Wilson, C., Ugliengo, P., Orlando, R., and Dovesi, R.: Vibrational spectrum of brucite, $\mathrm{Mg}(\mathrm{OH})_{2}$ : a periodic ab initio quantum mechanical calculation including OH anharmonicity, Chem. Phys. Lett., 396, 308-315, https://doi.org/10.1016/j.cplett.2004.08.047, 2004.

Peterman, E. M., Reddy, S. M., Saxey, D. W., Fougerouse, D., Snoeyenbos, D. R., and Rickard, W. D. A.: Nanoscale processes of trace element mobility in metamorphosed zircon, Contrib. Mineral. Petr., 174, 92, https://doi.org/10.1007/s00410-0191631-1, 2019.

Pouchou, J.-L. and Pichoir, F.: Quantitative Analysis of Homogeneous or Stratified Microvolumes Applying the Model "PAP", in: Electron Probe Quantitation, edited by: Heinrich, K. F. J. and Newbury, D. E., Springer US, Boston, MA., 31-75, 1991.

Reznitsky, L. Z., Sklyarov, E. V., and Galuskin, E. V.: Complete isomorphic join diopside-kosmochlor $\mathrm{CaMgSi}_{2} \mathrm{O}_{6}-$ $\mathrm{NaCrSi}_{2} \mathrm{O}_{6}$ in metamorphic rocks of the Sludyanka complex (southern Baikal region), Russ. Geol. Geophys., 52, 40-51, https://doi.org/10.1016/j.rgg.2010.12.004, 2011.

Rubatto, D. and Hermann, J.: Zircon formation during fluid circulation in eclogites (Monviso, Western Alps): implications for $\mathrm{Zr}$ and $\mathrm{Hf}$ budget in subduction zones, Geochim. Cosmochim. Ac., 67, 2173-2187, https://doi.org/10.1016/S0016-7037(02)013212, 2003

Secco, L., Martignago, F., Negro, A. D., Reznitskii, L. Z., and Sklyarov, E. V.: Crystal chemistry of $\mathrm{Cr}^{3+}-\mathrm{V}^{3+}$-rich clinopyroxenes, Am. Mineral., 87, 709-714, https://doi.org/10.2138/am2002-5-613, 2002.

Seydoux-Guillaume, A.-M., Fougerouse, D., Laurent, A. T., Gardés, E., Reddy, S. M., and Saxey, D. W.: Nanoscale resetting of the $\mathrm{Th} / \mathrm{Pb}$ system in an isotopically-closed monazite grain: A combined atom probe and transmission electron microscopy study, Geosci. Front., 10, 65-76, https://doi.org/10.1016/j.gsf.2018.09.004, 2019.

Shannon, R. D.: Revised effective ionic radii and systematic studies of interatomic distances in halides and chalcogenides, Acta Cryst. A, 32, 751-767, https://doi.org/10.1107/S0567739476001551, 1976.

Sherman, D. M.: Introduction to the Theory and Methods of Computational Chemistry, in: Molecular Modeling of Geochemical Reactions, edited by: John Wiley \& Sons Ltd., USA, 1-31, 2016.

Shorttle, O., Rudge, J. F., Maclennan, J., and Rubin, K. H.: A Statistical Description of Concurrent Mixing and Crystallization during MORB Differentiation: Implications for Trace Element Enrichment, J. Petrol., 57, 2127-2162, https://doi.org/10.1093/petrology/egw056, 2016.

Smyth, J. R. and Bish, D. L.: Crystal Structures and Cation Sites of the Rock-Forming Minerals, Boston, USA, 1988.

Smyth, J. R. and McCormick, T. C.: Crystallographic Data for Minerals, in: Mineral Physics \& Crystallography, American Geophysical Union (AGU), 1-17, 1995.

Soret, M., Agard, P., Dubacq, B., Plunder, A., and Yamato, P.: Petrological evidence for stepwise accretion of metamorphic soles during subduction infancy (Semail ophiolite, Oman and UAE), J. Metamorph. Geol., 35, 1051-1080, https://doi.org/10.1111/jmg.12267, 2017. 
Tsujimori, T. and Liou, J. G.: Coexisting chromian omphacite and diopside in tremolite schist from the Chugoku Mountains, SW Japan: The effect of $\mathrm{Cr}$ on the omphacite-diopside immiscibility gap, Am. Mineral., 89, 7-14, https://doi.org/10.2138/am-20040102, 2004.

Urusov, V. S. and Taran, M. N.: Structural relaxation and crystal field stabilization in $\mathrm{Cr}^{3+}$-containing oxides and silicates, Phys. Chem. Miner., 39, 17-25, https://doi.org/10.1007/s00269-0110456-x, 2012.

Van Hinsberg, V. J. V., Schumacher, J. C., Kearns, S., Mason, P. R. D., and Franz, G.: Hourglass sector zoning in metamorphic tourmaline and resultant major and trace-element fractionation, Am. Mineral., 91, 717-728, https://doi.org/10.2138/am.2006.1920, 2006.

van Westrenen, W., Allan, N. L., Blundy, J. D., Lavrentiev, M. Y., Lucas, B. R., and Purton, J. A.: Trace element incorporation into pyrope-grossular solid solutions: an atomistic simulation study, Phys. Chem. Miner., 30, 217-229, https://doi.org/10.1007/s00269-003-0307-5, 2003.

Wagner, J., Haigis, V., Künzel, D., and Jahn, S.: Trace element partitioning between silicate melts - A molecular dynamics approach, Geochim. Cosmochim. Ac., 205, 245-255, https://doi.org/10.1016/j.gca.2017.02.017, 2017.
Wigley, M., Dubacq, B., Kampman, N., and Bickle, M.: Controls of sluggish, $\mathrm{CO}_{2}$-promoted, hematite and K-feldspar dissolution kinetics in sandstones, Earth Planet. Sc. Lett., 362, 76-87, https://doi.org/10.1016/j.eps1.2012.11.045, 2013.

Whitney, D. L. and Evans, B. W.: Abbreviations for names of rock-forming minerals, Am. Mineral., 95, 185-187, https://doi.org/10.2138/am.2010.3371, 2010.

Wood, B. J. and Kleppa, O. J.: Chromium-aluminum mixing in garnet: A thermochemical study, Geochim. Cosmochim. Ac., 48, 1373-1375, https://doi.org/10.1016/0016-7037(84)90073-5, 1984.

Yang, P. and Rivers, T.: Chromium and manganese zoning in pelitic garnet and kyanite: Spiral, overprint, and oscillatory (?) zoning patterns and the role of growth rate, J. Metamorph. Geol., 19, 455-474, https://doi.org/10.1046/j.0263-4929.2001.00323.x, 2001

Yang, P., Rivers, T., and Jackson, S. J.: Crystal-chemical and thermal controls on trace-element partitioning between coexisting garnet and biotite in metamorphic rocks from western Labrador, Can. Mineral., 37, 443-468, 1999. 